\title{
Progesterone-Related Immune Modulation of Pregnancy and Labor
}

\section{OPEN ACCESS}

Edited by:

Elke Winterhager,

University of Duisburg-Essen,

Germany

Reviewed by:

Ana Claudia Zenclussen, Universitätsklinikum Magdeburg,

Germany

Maria Emilia Solano,

University Medical Center Hamburg-Eppendorf, Germany

*Correspondence:

Mark R. Johnson mark.johnson@imperial.ac.uk

Specialty section: This article was submitted to Reproduction,

a section of the journal

Frontiers in Endocrinology

Received: 11 January 2019

Accepted: 11 March 2019

Published: 29 March 2019

Citation:

Shah NM, Lai PF, Imami N and Johnson MR (2019)

Progesterone-Related Immune Modulation of Pregnancy and Labor.

Front. Endocrinol. 10:198

doi: 10.3389/fendo.2019.00198

\author{
Nishel M. Shah ${ }^{1}$, Pei F. Lai ${ }^{1}$, Nesrina Imami ${ }^{2}$ and Mark R. Johnson ${ }^{1 *}$ \\ ${ }^{1}$ Department of Surgery and Cancer, Chelsea and Westminster Hospital, Imperial College London, London, United Kingdom, \\ ${ }^{2}$ Department of Medicine, Chelsea and Westminster Hospital, Imperial College London, London, United Kingdom
}

Pregnancy involves a complex interplay between maternal neuroendocrine and immunological systems in order to establish and sustain a growing fetus. It is thought that the uterus at pregnancy transitions from quiescent to laboring state in response to interactions between maternal and fetal systems at least partly via altered neuroendocrine signaling. Progesterone (P4) is a vital hormone in maternal reproductive tissues and immune cells during pregnancy. As such, P4 is widely used in clinical interventions to improve the chance of embryo implantation, as well as reduce the risk of miscarriage and premature labor. Here we review research to date that focus on the pathways through which P4 mediates its actions on both the maternal reproductive and immune system. We will dissect the role of $\mathrm{P} 4$ as a modulator of inflammation, both systemic and intrinsic to the uterus, during human pregnancy and labor.

Keywords: pregnancy, progesterone, PIBF, immune modulation, immune response

\section{INTRODUCTION}

Progesterone (P4) is a steroid hormone primarily produced by the ovaries, placenta, and adrenal glands in humans. It has an essential role in the establishment and maintenance of pregnancy as well as the onset of parturition (1-3). In the myometrium, P4 signaling has been attributed to the suppression of myometrial contractility by hindering pro-inflammatory cytokine production (4). P4 can also regulate local and systemic inflammation. In peripheral blood leukocytes, P4 appears to dampen pro-inflammatory cytokine production, which consequently reduces T-helper subtype differentiation and proliferation (5-8). Furthermore, P4 blocks natural killer [NK] cell degranulation and, therefore, cytolytic function (9).

The corpus luteum is a major source of endogenous $\mathrm{P} 4$ at the early stage of pregnancy prior to 12 weeks of gestation. Once pregnancy has established beyond 12 weeks of gestation, P4 production is sustained by the placenta at concentrations far greater than those in non-pregnant women (10). During the course of pregnancy, the production of P4 gradually rises to serum concentrations ranging between 175 and $811 \mathrm{nmol} / \mathrm{L}$ in the third trimester compared to non-pregnant levels of 1-2 nmol/L and 35-50 nmol/L in the follicular and mid-luteal phases of the menstrual cycle, respectively (10-12). P4 is likely to have both paracrine and endocrine roles during pregnancy, and its local effects in tissues in close proximity to the placenta are likely to utilize higher concentrations of this hormone.

The importance of $\mathrm{P} 4$ in the maintenance of pregnancy is highlighted by a systemic decline in its concentration prior to the onset of labor in most animal models $(13,14)$. Intriguingly, this is not evident in humans, and thus it is expected that a different mechanism of change in physiological $\mathrm{P} 4$ action is required to mediate human labor $(15,16)$. This has been supported by both animal and human studies that have used abortifacient regimens, either by (i) inducing a decline in systemic P4 
levels, (ii) corpus luteum lysis or oophorectomy, or (iii) directly antagonizing the effects of $\mathrm{P} 4$ by the administration of an antiprogestin such as mifepristone (RU486) (17-22). It has been strongly suggested that the ability of RU486 to promote abortions and labor demonstrates such uterine processes are driven by "functional P4 withdrawal" in humans, which is mediated by altering the expression levels of $\mathrm{P} 4$ receptor (PR) isoforms and $\mathrm{PR}$ gene polymorphisms in reproductive tissues (23-25). In the immune system, indirect evidence of reduced P4 action at parturition is provided by studies that show a decrease in a lymphocyte-derived downstream immunomodulatory protein known as P4-induced-blocking factor (PIBF) (23, 26-28). Extracellular PIBF exerts an anti-abortive effect by interfering with availability of cytokines and NK cell activity (29); its content in urine has been observed to increase during pregnancy and dramatically decrease following childbirth. In pregnancy pathologies, including preterm labor (PTL) and pre-eclampsia, concentrations of maternal serum PIBF are low (30).

Animal pregnancy models have demonstrated that maintaining an elevated systemic concentration of P4 will prevent the onset of labor at term gestation and in models of inflammation-induced PTL (22). Evidence for P4-driven repression of human labor by pharmacological supplementation of this hormone is relatively less clear. Multiple studies have been carried out using different formulations and doses of P4 administered via different routes in women at risk of PTL, where some show benefit and others show no effect, but none show an adverse effect $(31,32)$. The most consistent beneficial response has been observed in women with a short cervix, who showed up to a $40 \%$ reduction in risk of PTL in a range of studies (33-35). The most consistent observation of an absence in response is in women with a multiple pregnancy, where P4 supplementation has demonstrated no effect in a number of studies (36-38). Failure of $\mathrm{P} 4$ supplementation to consistently prolong pregnancy supports the existence of functional progesterone withdrawal. At the same time, the findings of these studies suggest a process that links a shortening cervix to the onset of labor does seem to indicate responsiveness to $\mathrm{P} 4$ action.

Clinically, P4 is used to treat infertility, miscarriage and PTL, for which its efficacy has been extensively studied (39-41). The immunomodulatory effects of $\mathrm{P} 4$ in the endometrium and decidua are often suggested to promote embryo implantation and maintenance of pregnancy (40-42). P4 antagonism is an accepted approach to induce miscarriage or the onset of labor in situations of fetal malformation or loss. Typically, RU486 is administered before a prostaglandin (PG) analog to directly stimulate contractions. In the context of preventing miscarriage, the use of P4 is supported by the latest Cochrane review (42). In high risk groups for PTL, P4 is widely used to prevent premature onset of spontaneous labor and may significantly reduce an individual's risk of spontaneous preterm delivery, but the overall impact on absolute numbers of preterm births is small (0.01\%); thus P4 does not greatly impact on perinatal mortality, low birthweight, or neonatal death (43). In this review we will introduce the effects of $\mathrm{P} 4$ on reproductive tissue and provide a detailed understanding of its role as a modulator of both inflammation and immune response.

\section{RECEPTOR-MEDIATED ACTIONS}

\section{Nuclear PR}

Nuclear PR (nPR) isoforms PRA and PRB represent the two major PR isoforms in reproductive tissues (44-46). Both PRA and PRB are transcription factors that directly bind to P4 (10, 47). Following P4-nPR interaction, these receptors can also modulate intra-cytoplasmic signaling cascades to indirectly affect transcription factor activity (48). In addition to regulation by ligand binding, the transcriptional activity of nPR isoforms can be controlled by their expression level, posttranslational modification, and interaction with transcriptional co-regulators $(10,49)$.

Various co-regulators, both repressors and activators of gene transcription, can bind to both PRA and $\mathrm{PRB}$ to modulate their activity (50-53). PRA is a truncated from of PRB that has one less transcription activation domain, known as AF-3, at its N-terminus $(46,54)$. In an inactive state, both receptors reside in the cytoplasm while bound to chaperone proteins, which dissociates upon P4 binding to either (i) form dimers before translocating into the nucleus to interact with $\mathrm{P} 4$ response element (PRE) sequences at target gene promoter regions, or (ii) as a monomer that interacts with SRC-kinase complexes to activate extracellular signal-related kinases (ERK-1/2) and thus modulate transcription via the mitogen-activated protein kinase (MAPK) pathway $(45,55)$.

All reproductive tissues studied so far have been observed to express PRA and PRB in varying amounts, which is thought to result in differential expression of P4-responsive genes (56). It was previously thought that PRB has significantly greater transcriptional activity, which was attributed to its AF-3 domain located within the N-terminal 164 residues of its amino acid sequence (54). Whereas, PRA primarily functions as a liganddependent trans-dominant repressor of PRB activity (44). The ratio of PRA to $\mathrm{PRB}$ has consequently been considered to be an important factor for determining the status of P4 signaling. However, it is now known that PRA can also modulate transcriptional activity without the involvement of PRB, and they regulate the expression of distinct genes (4). In pregnancy, myometrial quiescence is suggested to, at least in part, be mediated by $\mathrm{PRB}$ and labor is associated with an increase in the PRA:PRB ratio that results in increased expression of pro-labor genes such as connexin-43 (Cx43), cyclooxygenase- 2 (COX-2), oxytocin receptor (OTR) and nuclear factor $\kappa \mathrm{B}$ subunit 2 (NF-кB2), which can potentiate myometrial contractility (4, $23,57)$. PRA not only represses PRB activity but also, in its unliganded state, acts as a transcriptional activator of Cx43 (5759). In addition to this, PRA is also capable of repressing the transcriptional activities of ER and GR, which illustrates the existence of cross-talk between their pathways $(44,60,61)$.

A number of studies have debated the existence of nPR expression in peripheral blood lymphocytes in humans, where it seems they are either not expressed or only expressed at low levels (62-64). Studies of pregnant mice have reported nPR expression on T cells from its quantification at the RNA and protein levels, but $\mathrm{nPR}$ expression in humans remains a controversy (65). PBMCs from both non-pregnant and pregnant women have 
been shown to contain mPRs with the use of immunoperoxidase staining methods (66) and, more recently in T-lymphocytes from non-pregnant women, with the use of mRNA and radioactive P4 ligand binding measurements (62).

\section{Membrane-Associated PR}

Non-classical PRs that are involved in extracellular signaling exist in addition to nPRs. The most commonly discussed types of non-classical PRs in pregnancy and parturition research are those that are integral membrane proteins, namely G-proteincoupled membrane progestin receptors (mPRs) and $\mathrm{P} 4$ receptor membrane components (PGRMCs). These have been classified to belong to the adipoQ receptor (PAQR) and b5-like heme/steroidbinding protein families, respectively (67). These two types of membrane-bound PRs differ from each other and to nPRs with regards to their tertiary structures, binding partners and intracellular signaling pathways.

The expression of mPRs was originally identified in fish species, where they were found to be particularly relevant in gamete function (68). They were subsequently identified in humans, but their localization in the plasma membrane has been debated and some studies suggest they reside in the endoplasmic reticulum instead (69-71). Five genetically distinct forms of $\mathrm{mPRs}$ are known, namely $\mathrm{mPR} \alpha$ (PAQR7), $\mathrm{mPR} \beta$ (PAQR8), mPR $\gamma$ (PAQR5), mPR $\delta$ (PAQR6), and mPR $\varepsilon$ (PAQR9) (72). These receptors each have a seven-transmembrane domain structure that includes an extracellular P4-binding domain, which has high affinity but limited capacity for P4 binding (73). Activation of mPRs has been shown to both suppress adenylyl cyclase activity and enhance phosphorylation of myosin light chain protein in human myometrial cells (74). Karteris et al. also showed inhibitory G-protein signaling through mPR can regulate $\mathrm{nPR}$ transactivation to increase transcriptional activity of ligand-activated PRB (74). The authors propose that this effect diminishes when PRA:PRB ratio increases, suggesting that mPR may act synergistically with PRB (74). P4-mPR binding can also lead to activation of MAPKs (75), which can alter the phosphorylation status of transcription factors. Kinases of the MAPK pathway have been suggested to play roles in $\mathrm{T}$ lymphocyte activation (76).

PGRMCs are encoded by two genes, PGRMC1 and PGRMC2, and their expression was originally discovered in rat and porcine hepatocytes $(77,78)$. Since then, PGRMC1 has been isolated from a range of human cells and tissues, including neuronal, breast, and reproductive tissues $(62,79-81)$, and have been found to localize to both the plasma membrane and organelle membranes (82-85). The ability of PGRMC1 to bind to P4 has been demonstrated with the use of radioactive $\mathrm{P} 4$ ligand binding measurements from porcine liver membrane fractions and, more recently, spectroscopy $(77,86)$. Both PGRMC1 and PGRMC2 are single membrane-spanning receptors that bind to heme and can interact with SERPINE1 mRNA-binding protein (SERBP1) to enable activation of second messenger pathways $(86,87)$. In granulosa cells, for example, PGRMC1 forms a complex with SERBP1 on the plasma membrane, and P4 binding to PGRMC1 in these cells can potentiate P4-associated anti-apoptotic effects (88). PGRMCs can also activate PKG activity upon P4 binding, which is also not a feature of classical mPRs $(86,89)$. In the endometrium, expression of PGRMC1 is upregulated in the proliferative phase of the menstrual cycle, as well as the maternalfetal interface and embryonic/fetal trophectoderm in pregnancy $(87,90)$, which suggests that PGRMCs are likely to have a role in the cell cycle within these tissues of the reproductive system.

Pregnant women have been shown to express mPRs and PGRMCs in T cells during pregnancy $(7,91,92)$. P4-driven modulation of $\mathrm{T}$ cell receptor (TCR) signal transduction and $\mathrm{T}$ cell function $(7,62-64)$ are potentially mediated by membranebound PRs in human $\mathrm{T}$ cells. The downstream pathways following TCR engagement involves MAPK phosphorylation and inositol trisphosphate (IP3) production, the latter of which promotes the release of $\mathrm{Ca}^{2+}$ stored in the endoplasmic reticulum (93). On T cells, however, P4 binding to PGRMC1 and classical mPRs results in increased intracellular $\mathrm{Ca}^{2+}$ mobilization and reduced phosphorylation of $\zeta$-chain-associated protein kinase 70 (Zap70) to modulate T cell activation and TCR-mediated immune responses (Figure 1) (63). Both pathways modulate phosphorylation of transcription factors that include NF- $\mathrm{kB}$, activator protein 1 (AP-1) and nuclear factor of activated $\mathrm{T}$ cells (NFAT), which are associated with pro-inflammatory gene expression as well as $\mathrm{T}$ cell activation and proliferation (Figure 1) (93).

In addition to mPRs and PGRMCs, it has also been suggested that OTR is a target for progestogen modulation. In human myometrium, $5 \beta$-dihydro-progesterone, but not $\mathrm{P} 4$, can inhibit oxytocin binding in vitro (95). OTR receptors are also expressed on $\mathrm{T}$ cells, where their activation has been shown to stimulate $\mathrm{Ca}^{2+}$ release in lymphocytes and, more importantly, P4 inhibited estradiol (E2)-induced expression of OTR mRNA in T cells (96).

\section{Nuclear GR}

Although P4 signaling is primarily nPR-mediated, P4 has also been shown to bind weakly to the nuclear glucocorticoid receptor (nGR), and this interaction may be an important mechanism of anti-inflammatory action by $\mathrm{P} 4$ in reproductive tissues (97). In primary myometrial cell cultures, we have previously shown that $\mathrm{P} 4$ acts via $\mathrm{nGR}$, rather than $\mathrm{PR}$, to suppress NF- $\mathrm{KB}$ dependent inflammation $(98,99)$. Furthermore, glucocorticoids have significant anti-inflammatory effects in immune cells, such as inhibiting the transcription of pro-inflammatory cytokines and chemokines in macrophages and increasing regulatory $\mathrm{T}$ cell (Treg) proportions in pregnant mice $(100,101)$. Promiscuous binding of P4 to nGR is likely to drive some of the previously observed glucocorticoid-like effects in reproductive tissues and immune cells. Recently, in vitro treatment of spleen-derived $\mathrm{T}$ cells obtained from nGR and nPR conditional knock-out mice during pregnancy demonstrated P4-induced T-cell death is mediated via nGR and not nPR (102); the authors of this study recommended in vivo validation to assess the impact of hormone bioavailability on P4-nGR binding on T-cell survival. Glucocorticoid excess in early pregnancy is associated with adverse effects on placental function, and it has the potential to convert myometrium from a quiescent state to an estrogenprimed contractile state in late pregnancy, by upregulating 


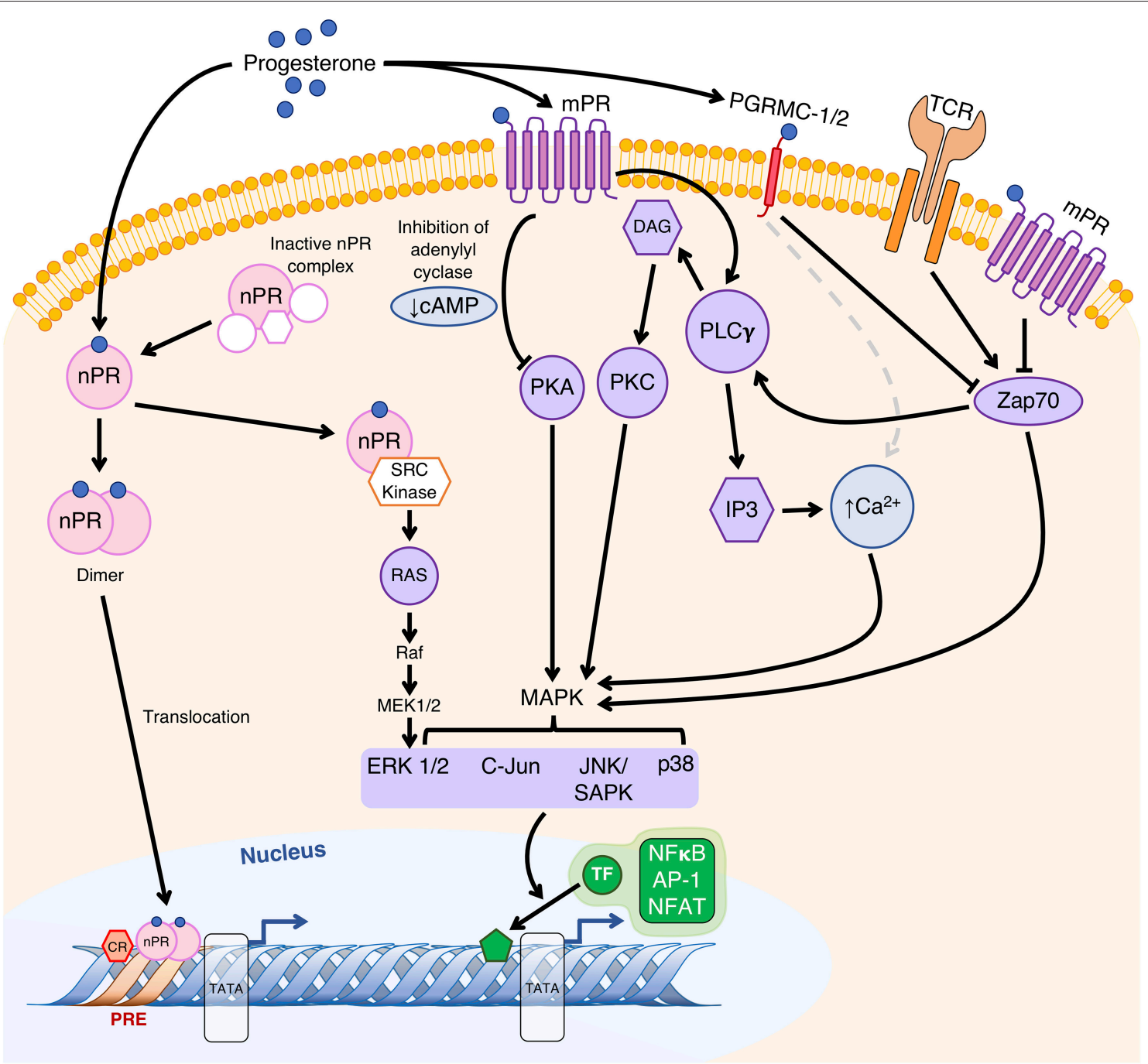

FIGURE 1 | Proposed mechanisms of P4-regulated gene transcription to modulate T cell function. Classically, extranuclear nuclear P4 receptors (nPR) exist in an inactive state until P4 binding, after which it forms a dimer and translocates to the nucleus to bind to P4 response element (PRE) sequences within gene promoter regions to alter their transcriptional activity. Alternatively, as a monomer, nPR-P4 acts via the Src kinase to activate the MAPK cascade. P4 bound to membrane P4 receptors (mPR) alters gene transcription regulated by second messengers (CAMP and $\mathrm{Ca}^{2+}$ ) and their associated extranuclear kinases (PKA and PKC) via the MAPK signal transduction cascade to result in phosphorylation of nuclear transcription factors (TF). Membrane-bound P4 receptors mPRs and P4 receptor membrane components (PGRMC) likely affect T cell receptor (TCR) signal transduction by modulating the activities of MAPKs through Zap70, as well as $\mathrm{Ca}^{2+}$ mobilization caused by phospholipase $\mathrm{C}_{\gamma}(\mathrm{PLC} \gamma)$-driven production of diacylglycerol (DAG) and 1,4,5-trisphosphate (IP3), which lead to modulation of pro-inflammatory gene expression and T cell activation via transcription factors NF-kB, AP-1 and NFAT. Adapted with permission from Mesiano et al. (55), and Mani et al. (94).

COX-2 expression in the amnion and placenta to induce parturition (103-106).

Like other members of the steroid hormone receptor family, nGRs are ligand-dependent transcription factors, which were first identified in thymus cells but have subsequently been observed in other human cell types (107). In a similar fashion to nPR, unliganded nGRs reside in the cytoplasm bound to heat shock proteins (HSPs) to form an inactive complex. The interaction between nGR and HSPs is disrupted by glucocorticoid binding to nGR, which then allows nGR to interact with its DNA-binding sites within the nucleus (107). The nGR family comprises a number of isoforms, but there are two principle variants, GR $\alpha$ and GR $\beta$, which share a similar relationship to that between PRA and PRB because GR $\beta$ is thought to be a negative regulator of GR $\alpha$ (108, 109). Much in the same way as PR, the nGR isoforms have varied tissue distribution and are responsible for regulating the expression of distinct genes (110). For the most part, these regulatory processes constitute the genomic actions of glucocorticoid-GR engagement. However, other signaling cascades independent of nGR contribute to glucocorticoid activity, including interaction with membranelocalized GR, and these represent alternative mechanisms of action $(111,112)$. 


\section{Membrane-Associated GR}

Similar to membrane-bound PR receptors and their interaction with $\mathrm{P} 4$, rapid effects of glucocorticoids are thought to occur via membrane GR (mGR). These receptors were first reported in a mouse lymphoma cell line and subsequently, using amphibian neuronal tissue, found to be coupled to G proteins (113-115). Both nGR and mGR appear to share components of the NR3C1 gene (116). At the same time mGR expression can be prevented in vitro using brefeldin $\mathrm{A}$, a Golgi apparatus transport inhibitor, which indicates a translocation of mGR to the plasma membrane $(117,118)$. Treatment of a human embryonic kidney cell line (HEK 293T) in vitro with glucocorticoids results in activation of the p38 MAPK signaling and pro-apoptotic activities (117, 119). In mice, dexamethasone binding to membrane fractions prepared from lung tissues has been assessed to demonstrate, in part, the existence of mGRs (120), but their ability to bind P4 has yet to be shown. To date, mGR expression has been demonstrated in human monocytes and $\mathrm{B}$ cells but not $\mathrm{T}$ cells $(118,121)$. Proteomics-based pathway analysis of a human acute lymphoblastic leukemia T-cell line (CCRF-CEM) stimulated with membrane-impermeable cortisol has identified RhoA signaling to most likely be activated upon mGR activation (122).

\section{P4 SUPPRESSION OF PREGNANCY-ASSOCIATED INFLAMMATION IN REPRODUCTIVE TISSUE}

In preparation for pregnancy, the maternal immune environment adapts to tolerate the semi-allogenic fetus and these adaptations are thought to be, in part, anti-inflammatory. The overall impact is likely to be mediated by the endocrine system via changes in concentrations of P4, E2 and human chorionic gonadotropin (hCG) as well as influenced by previous maternal exposure to paternal factors $(123,124)$. In fact, preparation for pregnancy begins during the menstrual cycle, where E2 and P4 optimize the uterine environment and vaginal mucosa for conception and implantation $(123,125)$. However, as a consequence, this optimum time to establish pregnancy is also the most vulnerable period for would-be mothers because the anti-inflammatory effects of P4 modulate the innate and adaptive immune systems in a way that results in limited responses to sexually transmitted pathogens (125-127). Locally, an increase in $\mathrm{P} 4$ activity during the luteal phase also directs endometrial decidualization, which is a key to enable successful trophoblast invasion and placentation in early pregnancy. P4 also stimulates other local factors in the reproductive tract, such as glycodelin $\mathrm{A}$ and transforming growth factor $\beta$ (TGF- $\beta$ ); these have tolerogenic biological activities, particularly in early pregnancy $(128,129)$.

Glycodelin-A is a secretory glycoprotein that is synthesized in endometrial glands and its secretion is related to P4 activity. Animal in vivo studies have demonstrated that the production of a glycodelin homolog can be increased following P4 stimulation and, following pregnancy, by hCG (130). It has a range of immunomodulatory properties that enhance maternal tolerance, which include reduced NK cytotoxicity, preferential apoptosis of Th1 subsets, and induction of tolerant dendritic cell (DC) phenotypes and Th2 cytokine production (128, 131-133).

In mammalian tissues, the TGF- $\beta$ superfamily of cytokines includes multiple sub-groups of polypeptide ligands. The TGF$\beta$ homologs form one of these sub-groups, which consists of TGF- $\beta 1$, TGF- $\beta 2$, and TGF- $\beta 3(134,135)$. Murine genetic knockouts for each of these TGF- $\beta$ homologs have demonstrated their differences in physiological roles, along with demonstration of their differential expression patterns during embryogenesis, and chimeric mice for TGF- $\beta 1$ knock-out and TGF- $\beta 2$ knock-in show their functions are not fully interchangeable $(136,137)$. In decidua, TGF- $\beta$ appears to regulate trophoblast invasion and placentation, and to be expressed in syncytio, chorionic, and extra-villous trophoblast $(138,139)$. During trophoblast invasion, TGF- $\beta$ has anti-proliferative, anti-invasive and proapoptotic actions, that regulate tissue growth and invasion, tissue remodeling, and angiogenesis required for successful placentation (140). In mice, anti-CD3 stimulation in the presence of TGF- $\beta$ mediates immune suppression via the induction of forkhead box P3 (FoxP3) expression in naïve T cells; FoxP3 is a specific lineage marker with functional relevance for Tregs, since mutations of the FoxP3 gene result in loss of Treg function, and different isoforms of FoxP3 confer different suppressive ability (141-144). Furthermore, TGF- $\beta$ polarizes DC maturation toward a tolerogenic phenotype (145).

Following implantation, concentrations of $\mathrm{P} 4$ increase, halting pro-inflammatory and cytotoxic leukocytes recruitment via GR suppression of cytolytic function mediated by PIBF blockade of degranulation (123). Once pregnancy is established, the antiinflammatory effects of $\mathrm{P} 4$ observed prior to implantation are enhanced. In human and animal models, P4 has been shown to have both systemic and tissue-specific anti-inflammatory effects, repressing both NF- $\kappa \mathrm{B}$ and MAPK pathways to downregulate COX-2 expression $(4,98,146-148)$. This represses local PG production that would otherwise increase placental corticotropin release hormone $(\mathrm{CRH})$ to potentiate NF- $\kappa$ B signaling to drive pro-inflammatory gene expression and leukocyte recruitment (149). Additionally, $\mathrm{P} 4$ has been shown to halt IкB $\alpha$ degradation, which prevents NF- $\mathrm{B}$ activation and so downregulate the expression of labor-associated genes such as OTR and Cx43, and inhibit pro-inflammatory cytokine production in reproductive tissues and immune cells (150-153). However, P4 is far less effective once inflammation is established, which may be attributed to the expression ratio of $\mathrm{PR}$ isoforms in reproductive tissues $(154,155)$.

Primary myometrial cell cultures have previously been used to show that altering PR expression to favor PRA leads to increased $\mathrm{P} 4$-driven pro-inflammatory gene expression, whereas the reverse is true if PRB expression is dominant $(3,4)$. Small alterations in placental PR levels can modulate Th1 cytokine production and subsequently PTL risk (156). As discussed above, differential expression of PR isoforms is thought to contribute to the onset of labor (57). Murine experiments have shown that, during both pregnancy and labor, PRB and NF- $\kappa \mathrm{B}$ pathways remain in opposition, and responsiveness to exogenous $\mathrm{P} 4$ may attenuate maternal inflammatory processes thereby tipping the 
balance to favor PRB $(157,158)$. Outside the maternal-fetal interface, $\mathrm{P} 4$ concentration in the systemic circulation tends to be relatively low in humans and its immunomodulatory effects may be determined by lymphocyte sensitivity to the hormone (159). Our own analysis of $\mathrm{P} 4$ effects during pregnancy suggest that the systemic effects of $\mathrm{P} 4$ become less pronounced from $\sim 34$ weeks of gestation (160), which coincides with increased expression of activation markers on circulating and decidual $\mathrm{T}$ cells in late pregnancy and prior to the onset of labor $(161,162)$.

Cervical ripening occurs in the presence of increased cervical vascular permeability, inflammatory cytokine and PG production, macrophage numbers and a reorganization of collagen cross-linking to prepare the cervix to open (163). P4 is thought to prevent some of these changes. However, RU486 initiates uterine activity but does not promote cervical ripening in rhesus macaques (164), and RU486 can act as a PR agonist in the event of, for example, changes to protein expression ratio of PR coactivators to corepressors or the absence of $\mathrm{P} 4$ binding (53, 165-168). On the other hand, P4 treatment of endometrial cell cultures has been shown to upregulate collagen accessory proteins that, if directly translatable to the in vivo condition, would contribute to the maintenance of cervical structure (169, 170). The effect of $\mathrm{P} 4$ on the cervix may be mediated through reduced inflammatory cell infiltration $(171,172)$. For example, analysis of murine cervical leukocyte infiltration has previously shown a dominance of monocytes after lipopolysaccharide (LPS) exposure and neutrophils after RU486 exposure, which suggested that P4 may influence neutrophil chemotaxis (173).

PTL is often associated with a reduction in resident inflammatory cells, such as macrophages, when infection is a factor of consideration (174). Our own unpublished observations from longitudinal analysis of cervical mucus obtained from women with a high risk of preterm delivery or short cervix, whilst receiving vaginally-administered $\mathrm{P} 4$ treatment, found an increase in populations of total innate cells, which consisted of predominantly neutrophils as well as stable proportions of monocytes and macrophages. This suggests P4 may act to maintain the leukocyte composition in cervical mucus to reduce susceptibility to infection-mediated PTL. However, the protection of cervical mucus during pregnancy may not be entirely reliant on its immunological properties; its permeability to microbial infiltration or similar aspects may have a role to play instead (175).

\section{P4 MODULATION ON INNATE IMMUNE FUNCTION}

The reports mentioned above suggest that P4 reduces inflammatory cell infiltration into the cervix and cervical mucus. Furthermore, in vitro studies have demonstrated P4 inhibition of human neutrophil degranulation and free radicals generation, whilst also promoting an increase of tolerant CD4 T cells expressing glycoprotein A repetitions predominant (GARP) protein and with a $\mathrm{CD} 127^{\mathrm{lo}} \mathrm{FoxP}{ }^{+}$phenotype that can produce interleukin (IL-) IL-10 and IL-17 as well as vascular endothelial growth factor (VEGF) $(176,177)$. P4 can inhibit mature DCs and DC-mediated proliferation of $\mathrm{T}$ cells, favoring immature DCs that promote immune tolerance (10). The addition of $\mathrm{P} 4$ to in vitro co-culture of rat DCs and $\mathrm{T}$ cells can reduce $\mathrm{T}$ cell proliferation in response to LPS (178). Tolerant DCs have reduced expression of co-stimulatory markers CD40, CD80, and CD86, which are needed for $\mathrm{T}$ cell activation and secrete the immune regulatory cytokine IL-10 that potentiates Treg suppressive activity $(10,179,180)$.

As well as promoting tolerant immune cells, progestogens also suppress the activity of potent type I interferon (IFN)-producing DCs. For example, by binding to GR, medroxyprogesterone acetate (MPA), but not norethisterone (NET) or levonorgestrel (LNG), can reduce human IFN- $\alpha$ production by plasmacytoid DCs (pDCs) in response to inactivated virus or TLR ligands in vitro in a concentration-dependent manner (181). IFN- $\alpha$ can potentiate the maturation of conventional DCs (cDCs) that interact with $\mathrm{T}$ cells, and are able to induce IL-10-producing Tregs (182).

In vitro experiments using PIBF-expressing human leukemia cell lines have demonstrated that P4 may actually enhance the innate immune response by increasing expression of TLRs, in particular TLR4, along with other proteins involved in their signaling (183). Observations by Schatz et al. showed in human decidua that TLR4 expression is significantly increased in first trimester DCs when compared with luteal phase or pre-decidual stromal cells. Furthermore, the expression of TLR4 on these DCs was preferentially increased in the first and third trimesters of pregnancy, but remained greater than the expression on interstitial trophoblasts irrespective of gestation (184). Similarly, Ziegler et al. showed, using PBMCs, that IFN- $\alpha$ production by TLR7-stimulated pDCs was low in early pregnancy relative to non-pregnant controls and subsequently increased with gestation, whereas TLR4-induced TNF- $\alpha$ production by monocytes was greatest in early pregnancy and subsequently decreased (185). These results indicated that although DCs in pregnancy have an immune tolerant phenotype with a reduced ability to activate $\mathrm{T}$ cells, their increasing TLR expression suggests they can still function effectively against invading pathogens to initiate an immune response.

Although TLR4 primarily interacts with LPS, it can also interact with host-derived molecules released during tissue damage in, for example, non-infective PTL and pre-eclampsia (184). It seems DC modulation by P4 may be designed to enhance their ability to respond to innate immune stimuli whilst suppressing $\mathrm{T}$ cell activation in order to promote fetal antigen tolerance. This has been demonstrated in pregnant mice, where P4 treatment can increase myometrial IFN$\gamma$-expressing neutrophils as well as cervical active matrix metallopeptidase 9 (MMP9)-positive neutrophils and monocytes (158). The secretory endometrium in non-pregnant women is also associated with increased TLR gene expression, which is likely to reflect a specific innate protective consequence of endocrine immunomodulation (186).

Injectable P4-based contraceptives in non-pregnant women are associated with a fall in chemokines monocyte chemoattractant protein 1 (MCP-1), macrophage-derived chemokine (MDC) and fractalkine, along with cytokines IL-15 
and IL-12p40, and the platelet-derived growth factor (PDGF)AA in cervico-vaginal fluid (187). Both MCP-1 and MDC are chemokines primarily involved in the recruitment of monocytes, monocyte-derived DCs and NK cells to sites of inflammation, although they are also thought to attract memory $\mathrm{T}$ cells and specifically Th2 subsets in the presence of antigen-induced inflammation (188-190). Fractalkine can attract and activate NK cells when present at sites of inflammation and may enhance the recruitment of cytotoxic T cells in the endometrium $(191,192)$. Similarly, IL-12p40 attracts macrophages and promotes the migration of activated DC, whereas IL-15 facilitates B-cell activity, NK cell generation and maintenance, and supports long-lasting CD8 T cells $(193,194)$. Platelet-derived growth factor (PDGF)-AA is a pro-angiogenic factor produced by various cell types, such as platelets, macrophages, endothelial cells and smooth muscle cells, and it has been shown to have a role in cellular proliferation, angiogenesis, inflammation, and tissue repair (195). In the upper genital tract, P4 also has anti-inflammatory effects, where P4 and E2 together, but not P4 alone, decrease TLR expression in cultured human fallopian tube epithelial cell lines (196). Similar effects have been observed in the amniotic membrane epithelium, where in vitro $\mathrm{P} 4$ treatment of explants suppressed LPS-induced release of IL-6, IL-8, TNF- $\alpha$, and IL-10 (197) in tissues obtained from non-laboring pregnant women.

In addition to tissue-specific effects, $\mathrm{P} 4$ has a range of immunosuppressive effects on other innate leukocytes. P4 can suppress macrophage activation induced by both LPS and IL4 in vitro and reduce both nitric oxide synthase 2 (iNOS) and arginase activity in a dose-dependent manner irrespective of the stimuli used (198). Furthermore, P4 pre-treatment of murine macrophages can inhibit LPS and CpG oligodeoxynucleotide (ODN)-induced IL-6 and NO production, as well as upregulate TLR4 expression (199), but it is uncertain whether P4 is acting by $\mathrm{nPR}$. Jones et al. (200) postulated that these effects on murine macrophages are mediated $v i a$ the GR receptor and, more recently, Lu et al. (201) suggested $\mathrm{P} 4$ may be acting via mPR; although both studies did not use pregnancy models and the macrophages were obtained from male mice. P4 may modulate the differentiation of macrophages into tolerant phenotypes in the uterus during early pregnancy, where immune mediators such as HLA-G, and cytokines IL-4, IL-10, and M-CSF are thought to regulate macrophage differentiation to promote phenotypes tolerant to the invading trophoblast tissue (202-206). Typically, macrophages differentiate into M1 or M2 phenotypes depending on a classical or alternative activation pathway, both of which can be promoted by microbes and microbial products, but each has a specific cytokine stimulation repertoire that is either pro-inflammatory (IFN, TNF) or anti-inflammatory (IL4, IL-13) (207, 208); M1-M2 dichotomy is thus considered to be analogous to T-helper (Th1-Th2) phenotypes. MPA is a potent progestin that also has glucocorticoid activity. Tsai and colleagues have demonstrated that in vitro MPA treatment of a human monocyte cell line can stimulate differentiation to produce immune-tolerant M2 macrophages, which are able to induce decidualization of endometrial stromal cells, potentiate trophoblast invasion and resist responses to TLR agonists, thereby creating an environment typically associated with successful pregnancy (209).

\section{P4-MODULATION OF ADAPTIVE IMMUNE RESPONSES AND OVERLAPPING SYSTEMS}

Human PBMCs are thought to express a number of steroid receptors, such as PR, GR, and E2 receptor (ER) $(210,211)$. However, the majority of $\mathrm{P} 4$ effects on immune function are mediated via GR and PR. For example, CD8 T cells express nPRs, which can be increased by immunotherapy for successful treatment of recurrent miscarriages $(66,212,213)$. Whereas, mPRs have been detected in Tregs isolated from pregnant women, which has been observed to increase in expression with advancing gestation and subsequently decrease at labor (214). Steroid hormone sensitivity of Tregs has been demonstrated by a study on patients with multiple sclerosis (MS), whereby in vitro treatment with E2, P4 and the combination of both hormones in mixed lymphocyte reaction (MLR) cultures enhanced Treg suppressive activity for both MS and healthy control subjects to a similar extent (215). The findings of this study suggest that Tregs may not increase in number in vitro, but their suppressive activity may be increased in response to proliferating responder $\mathrm{T}$ cells stimulated by allo-antigen in the presence of E2 and P4. In mice, GR engagement increases Treg immunosuppressive function during pregnancy, and P4 binding to nGR may mediate such an effect in humans $(101,102)$. GR agonists are also potent direct suppressors of Th1 differentiation in mice (8), and inducers of T cell apoptosis (216).

During mouse pregnancy, systemic and uterine Treg proportions and their suppressive activity have been shown to be enhanced with P4 supplementation and blocked by RU486, but this does not prevent spontaneous fetal loss in abortion-prone mice $(65,217)$. Findings from the latter study relate to early and mid-pregnancy, when the maternal response to the initial surge of fetal antigen is vital for maintaining pregnancy, and the murine abortion model used was previously found to produce poorly functioning maternal Tregs that contributed to their high susceptibility to miscarriage (218). Thus it is possible that expansion of these Tregs by $\mathrm{P} 4$ would not be sufficient to improve tolerance to fetal antigen. This is supported by the observation that adoptive transfer of Tregs from normal pregnant to abortion-prone mice in early pregnancy improves placentation and reduces reabsorption rates (218-220). Vaginal P4 supplementation in mice can increase decidual Tregs and pre-treatment with $\mathrm{P} 4$ is associated with protection against endotoxin-induced PTL (158).

In humans, however, our own in vivo study showed that Treg proportions gradually fall during the course of pregnancy in women who were given $\mathrm{P} 4$ treatment, but their cell-mediated IL-10 responses were comparable to untreated pregnancies (160). Mjösberg et al. showed that P4 reduces functionally suppressive Tregs in second trimester human pregnancies (221), whereas our findings showed an initial peak in Treg proportions compared to non-pregnant controls, followed by a steady 
decline in late pregnancy (160). We proposed that this fall may reflect the overall anti-inflammatory effect of P4 and suggested that alternative immunomodulatory pathways other than that provided by Tregs are at play. However, Tsuda et al. have shown that effector Tregs in the decidua are clonally expanded in the third trimester of pregnancy (222). Therefore, alternative explanations for our own observations from peripheral blood could be the selective recruitment of fetal-specific Tregs to the maternal-fetal interface or relative expansion of other leukocyte populations.

In human $\mathrm{T}$ cell clones, $\mathrm{P} 4$ modulates resting peripheral blood $\mathrm{T}$ cell differentiation into Th1, Th0 or Th2 clones, promoting Th2 subsets as shown by the increased production of IL-4 (10). $\mathrm{P} 4$ also induces enhanced production of IL- 5 and IL- 4 by T cells, as well as detectable amounts of IL- 4 in Th1 cell lines, enabling Th2 dominance in pregnancy (10). Increased in vivo (gestation-related) and in vitro extracellular P4 concentrations can result in the suppression of IFN- $\gamma$ production in human CD8 T cells during pregnancy, which has been attributed to hypermethylation of the IFN- $\gamma$ gene promoter based on findings from pregnant mice $(7,223)$. In murine pregnancy, galectin-9 (Gal-9) is a biologically active protein found in the cytoplasm and extracellular environment that also has a unique binding specificity for glycans (224). Gal-9 can promote the induction of Tregs and apoptosis of Th1 cells, by binding to Tcell immunoglobulin and mucin-domain containing-3 (TIM-3) expressed on the surface of terminally differentiated Th1, but not Th2, cells and its binding downregulates Th1 and Th17 responses $(225,226)$. The gal-9/TIM-3 pathway has been shown to be susceptible to $\mathrm{P} 4$ immunomodulation in mice placenta. It has been proposed that $\mathrm{P} 4$ alters gal- 9 and TIM- 3 expression by NK and T cell subsets, along with CD107a expression by TIM$3^{+}$dNK cells and dNKT cells (227). CD107a is a useful surrogate marker for NK cell activity because it correlates well with both cytokine secretion and target cell lysis (228). Arruvito et al. have shown that peripheral blood NK cells express classic nPR, and this expression is restricted to mature $\mathrm{KIR}^{+}$phenotypes (229). P4 activity in these cells is associated with an increased susceptibility to both suppression of IL-12-induced IFN- $\gamma$ secretion and caspase-dependent apoptosis (229). In contrast, human uNK cells have no PR expression and P4 does not have direct effects on their biological activity $(230,231)$. Murine work suggests that these effects are predominantly mediated by PIBF (232-234).

The menstrual cycle provides a human model for the in vivo effects of P4 that is alternative to that of pregnancy. Despite slightly conflicting data across studies, they have shown overall that the P4-rich luteal phase of the menstrual cycle is associated with a decline in Tregs, leukocyte proliferation, and IFN- $\gamma$ production, as well as a shift toward Th2 cytokine production (235-240). There is evidence to suggest the effect of Tregs in this context and during pregnancy may be influenced by previous exposure to paternal antigens, and therefore greater parity and sexual activity with a male partner prior to the index pregnancy may act to enhance P4 action $(236,241,242)$. P4 may also suppress primary immune responses by naïve $\mathrm{T}$ cells, since functionally active $\mathrm{nPR}$ receptors are expressed in the thymus and these are thought to be involved in thymic involution during pregnancy $(1,243)$.

P4 and low dose E2 administration to female mice have been associated with reduced B cell lymphopoiesis, which suggests that B-cell development in bone marrow is subject to $\mathrm{P} 4$ immunomodulation (244). Murine B cells have been shown to express $\mathrm{nPR}$ at the mRNA level and the preference for Th2-skewed responses with $\mathrm{P} 4$ interactions suggest that P4 is likely to influence the humoral immune response. B cell and endometrial cell in vitro co-culture in the presence of $\mathrm{P} 4$ has been shown to suppress $\mathrm{B}$ cell antigen presentation due to reduced expression of co-stimulatory molecules CD80 and CD86 (245). However, activation-induced deaminase mRNA synthesis, which is required to promote a diverse immunoglobulin repertoire and achieved by somatic hypermutation and class switch recombination among other mechanisms, in activated

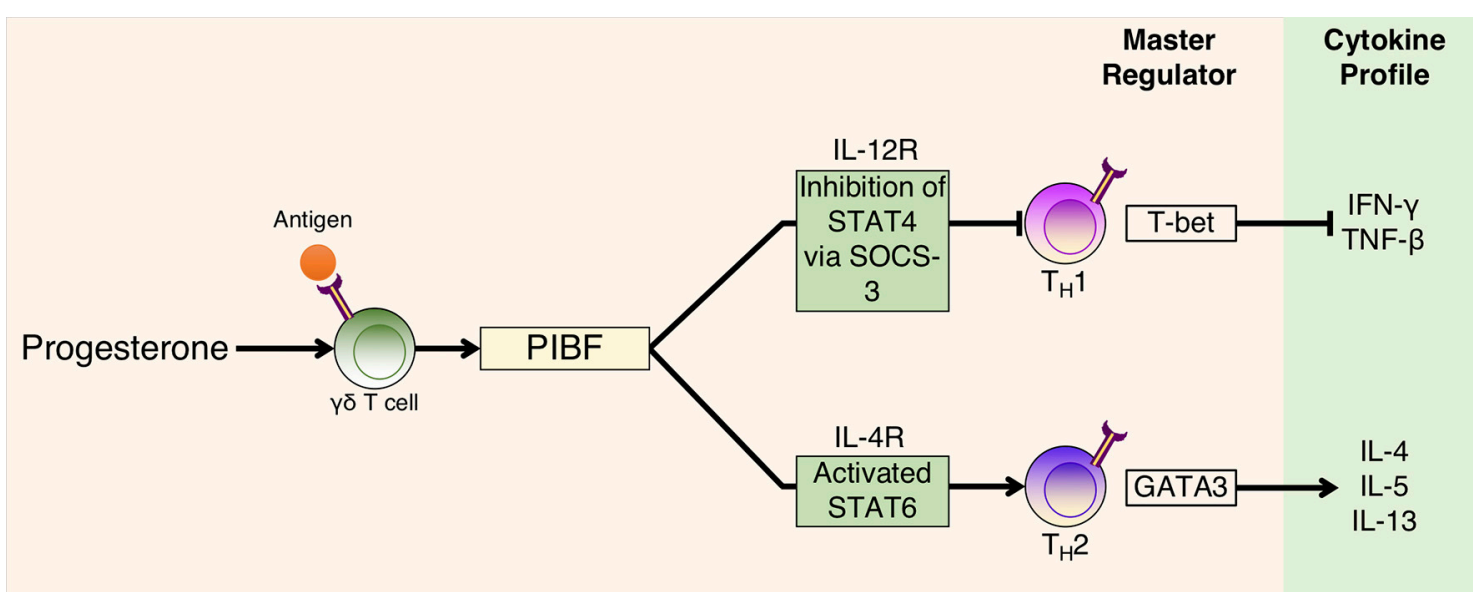

FIGURE 2 | P4-dependent PIBF action on T cell differentiation and cytokine production. P4 binds to PR found in P4-sensitive $\gamma \delta$ T cells that are activated having already interacted with fetal/paternal antigen. PIBF is subsequently released, which binds to the PIBF receptor, which is heterodimerized with the IL-4 receptor, to activate the STAT6 transcription pathway for Th2 cytokine production. On Th1 cells, PIBF acts to inhibit the STAT4 pathway by promoting SOCS-3 interaction with the IL-12R receptor to inhibit Th1 cytokine production. Adapted with permission from Shah (278). 
mouse splenic B cells is reduced with P4 treatment (246, 247). In addition, during respiratory influenza A infection, female mice treated with $\mathrm{P} 4$ and levonorgestrel produce fewer antibodies in sera and locally in bronchial-alveolar lavage fluid (248). Therefore, it is surprising that whilst P4 promotes a Th2-dominant immune profile, it also negatively regulates the production of high-affinity antibodies. With significant fetal antigen exposure in pregnancy, however, this is probably a protective feature. The Th2 bias that is thought to be characteristic of $\mathrm{P} 4$ treatment is in fact associated with increased asymmetric antibody production, which may have a protective role during pregnancy (249).

Despite the wealth of data available, the exact mechanism of P4 action on lymphocytes is still poorly understood and this can be partly attributed to varied outcomes of studies that examined their expression of nPRs (250). The observed rapid actions of some steroid hormones fail to agree with a classical genomic mechanism of action through $\mathrm{nPR}$, which is commonly

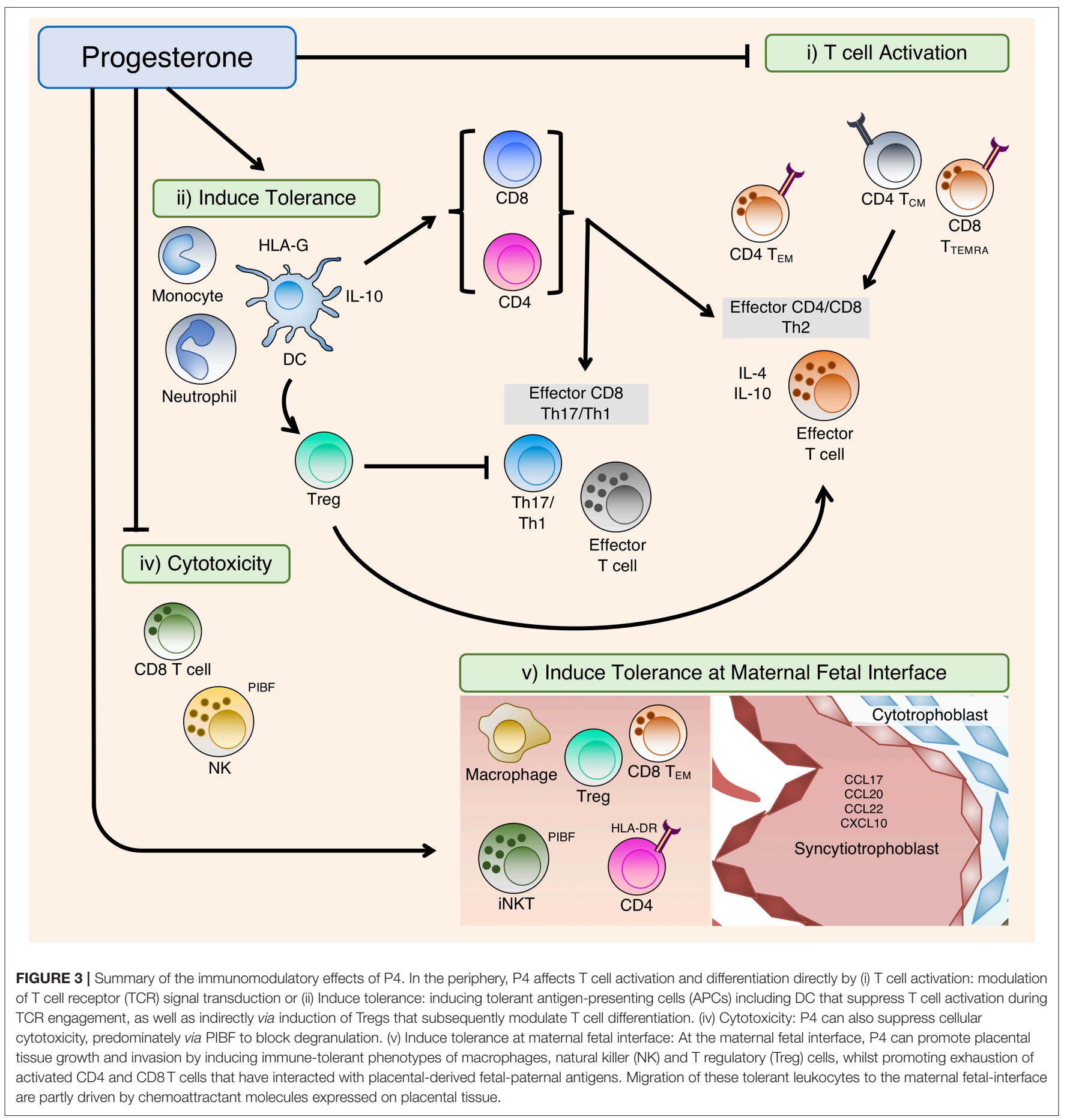


associated with a longer lag time $(250,251)$, and thus mPRs are more likely to be the mediators of $\mathrm{P} 4$ activity in these cases (62). Of note, a study by Dosiou et al. on lymphocytes taken from non-pregnant women of reproductive age demonstrated $\mathrm{mPR} \alpha$ expression on $\mathrm{CD}^{+}$, but not $\mathrm{CD} 4^{+}$, cells, which can be increased by a P4-dominant environment like that of the mid-luteal phase of the menstrual cycle (62); the same was not true for $\operatorname{mPR} \beta$ expression. Their results also demonstrated specific binding of $\mathrm{P} 4$ to plasma membranes of $\mathrm{T}$ cells and showed a concentration-dependent activation of inhibitory Gproteins in Jurkat cells (62). Chein et al. showed that RU486 suppressed P4-mediated rapid increases in $\mathrm{Ca}^{2+}$ in human $\mathrm{T}$ cells expressing mPRs, but enhanced the inhibitory effect of P4 on phytohemagglutinin (PHA)-induced cell proliferation (252). Therefore, it seems likely that the mechanism by which $\mathrm{P} 4$ elicits its activity may vary with different lymphocyte subsets and include both genomic and non-genomic pathways via different receptors and downstream effects.

\section{P4-INDUCED BLOCKING FACTOR (PIBF)}

PIBF is a PR-regulated gene and potent immune-modulator (253). It is expressed most abundantly as a protein composed of 757 amino acid residues and has a predicted molecular mass $90 \mathrm{kDa}$ (254). This form has been shown to be associated with the centrosome and may have a role regulating the cell cycle (255). However, several other shorter splice variants have been recognized with tissue-specific intra- and extracellular expression (255-257). These short isoforms are also thought to be ligands for the PIBF receptor $(256,258)$. Highly proliferative cells such as trophoblast, mesenchymal stem cells, and tumor cells all express $\operatorname{PIBF}$ (257, 259, 260). PIBF expression is hormone-dependent, and the expression of PIBF is increased during pregnancy (159). Studies using murine models of hematological cancers have shown that PIBF mRNA levels are increased and decreased in the presence of P4 and RU486, respectively $(183,212)$. The PIBF receptor appears to be glycosylphosphatidylinositol (GPI)-anchored and can form a heterodimer with the IL-4 receptor (IL-4R) via the latter's $\alpha$-chain component (261). PIBF is thought to mediate a large proportion of P4-regulated effects in lymphocytes during pregnancy $(6,262)$, which include cytokine synthesis and subsequent T-helper subtype differentiation and proliferation $(5,6)$. T cell effector functions modulated by PIBF include Th2type cytokine synthesis, suppression of cytotoxic T and NK cell activity, and arachidonic acid synthesis $(5,9,27)$.

\section{P4-Dependent Regulation of PIBF Expression}

$\mathrm{PR}^{+} \mathrm{T}$ cells in the peripheral circulation in pregnancy are predominantly $\gamma \delta^{+}$or $\mathrm{CD}^{+} \mathrm{T}$ cells that express PRs once activated after immune recognition of fetal and placentalderived antigens, which occurs in a hormone-independent manner $(66,263,264)$. The quantity of $\gamma \delta^{+}$PR-expressing $\mathrm{T}$ cells in peripheral blood in notably higher in pregnant than non-pregnant women, though comparatively less than decidua where they comprise a large proportion of all $\mathrm{T}$ cells during pregnancy (264). Importantly, $\gamma \delta \mathrm{T}$ cells interact with unprocessed foreign antigens in an MHC non-restricted manner and with non-polymorphic Class I or Class II like molecules $(265,266)$. Note that PR expression can be stimulated by any allo-antigen, not necessarily feto-placental, and $\mathrm{T}$ cells can exhibit increased PR expression following organ transplantation and blood transfusion in non-pregnant women (267). Maternal interaction with fetal antigens during pregnancy is a potentially important step in PR expression and murine studies have suggested that placenta-derived nonclassical HLA molecules, such as HLA-C, serve to present fetal/paternal antigens to maternal lymphocytes (268). In pregnancy, the trophoblast, which forms the interface between maternal and fetal compartments, expresses a number of nonclassical MHC class I molecules, including HLA-C, HLA-E, and HLA-G proteins. The expression of HLA-G, in particular, is enhanced in the presence of P4 and cytokines IL-10 and IFN- $\gamma(269,270)$.

Our own studies have shown that PIBF expression on $\mathrm{CD} 8^{+} \mathrm{TCR}-\gamma \delta^{+} \mathrm{T}$ cells is increased during healthy pregnancy, independent of in vitro $\mathrm{P} 4$ stimulation, and this appeared to be dominant in the second trimester of pregnancy (271). It is nevertheless likely that our observation of a gestational variance represented relative differences in endogenous $\mathrm{P} 4$ and fetal antigen exposure prior to culture. On the other hand, Cohen et al. proposed that $\mathrm{P} 4$ supplementation and endogenous elevation of $\mathrm{P} 4$ during the menstrual cycle were sufficient to induce a rise in PIBF concentrations, but the effects of paternal antigen exposure were not discussed $(254,272)$.

\section{Suppression of Pro-inflammatory Cytokines}

Szekeres-Bartho et al. were the first to demonstrate that P4treated lymphocytes obtained from healthy pregnant women released PIBF, which was able to block both cytotoxic activity and prostaglandin F2 $\alpha$ (PGF2 $\alpha$ ) synthesis in lymphocytes; women with clinical symptoms of threatened preterm delivery failed to synthesize PIBF (27). In this instance, PIBF functions like a cytokine and binds to its GPI-anchored protein receptor at the plasma membrane to mediate intracellular effects. Since then, other studies have demonstrated that PIBF concentrations in the urine and plasma of women who experienced spontaneous preterm birth is significantly reduced, and that cytokine production is skewed toward a pro-inflammatory profile with reduced IL-10 and increased IL-6 and IFN- $\gamma(5,273)$. Additionally, murine experiments that tested the influence of embryo-derived extracellular vesicles showed those that contained PIBF increased IL-10 production by CD8 T cells in vitro (274). Thus, PIBF appears to be important for maintaining pregnancy by contributing to the mechanisms of immune tolerance. However, not all lymphocytes express either PIBF or PR (229, 262, 275-277), and PIBF may exert some if its actions via mechanisms independent of PR (274).

Th2 cytokines are induced by PIBF binding to its receptor whilst heterodimerized with IL-4R to result in phosphorylation 
of Jak1, which activates signal transducer and activator of transcription (STAT) 6 and suppressor of cytokine signaling 3 (SOCS-3) protein. SOCS-3 binds to IL-12R to inhibit STAT4 phosphorylation (Figure 2) (261, 279), which is an effect that is abrogated with the use of an anti-IL-4R antibody (261). A consequence of this Th2 cytokine bias is the modulation of humoral immune responses. For example, PIBF exposure to in vitro cultures of hybridoma cells can cause the expression of PIBF in lymphocytes to be associated with an increase in asymmetric antibody production, which has the potential to provide fetal protection during pregnancy $(249,280)$.

The effects of $\mathrm{P} 4$ are not limited to Th2 cytokine production. Originally, Szekeres-Bartho et al. also showed that both P4 and PIBF prevent PGF2 $\alpha$ synthesis, and PIBF appears to do this by inhibiting phospholipase A2 activity, which leads to reduced arachidonic acid concentrations (27). PGF2 $\alpha$ promotes myometrial smooth muscle contractions and so PIBF-driven reduction in PGF2 $\alpha$ stimulation of myometrial cells potentially helps to maintain uterine quiescence. However, PGs can mediate alternative mechanisms of $\mathrm{P} 4$-associated immunomodulation (281, 282). For example, in allergic COX-2 knock-out mice, synthetic PGF $2 \alpha$ and PGI2 promote Th17 cell differentiation of $\mathrm{CD}^{+}{ }^{+} \mathrm{T}$ cells in vitro (283). Similarly, at sites of inflammation in mice where PGE2 is abundant and T cell responses are Th17skewed, PGE2 serves to shift the cellular production of IL$17 \mathrm{~A}$ to IFN- $\gamma$ in order to promote Th1 cell proliferation and cytokine production (284). Therefore, in contrast to PGF2 $\alpha$, PGE2 inhibits effector $\mathrm{T}$ cell function and proliferation whilst promoting Treg differentiation, thus initiating and resolving mucosal inflammation $(281,284)$. In fact, in murine studies, arachidonic acid has been shown to upregulate activated PGE2producing DCs that are associated with increased FoxP3 ${ }^{+}$Tregs and reduced $\mathrm{T}$ cell proliferation (285).

\section{Anti-cytolytic Activity}

In addition to promoting a Th2 dominant cytokine profile, P4 also can upregulate HLA-G expression on trophoblast cells that mediate $\gamma \delta \mathrm{T}$ cell activation and assist the invading trophoblast tissue to evade host defenses, such as decidual NK (dNK) cells, by acting as a ligand for inhibitory receptors expressed on these cells $(10,269)$. Human uNKs express GR and not PR, and P4 appears to suppress NK cell activation and IFN- $\gamma$ production via GR activity by altering STAT4 and IKB phosphorylation (286). PIBF-expressing granulated cells have been observed in mouse decidua and PIBF colocalizes within the cytoplasmic granules of dNK cells (234). PIBF may also have a direct action on NK cell efficacy in pregnancy; in vitro experiments on decidual mononuclear cells have shown that both P4 and PIBF decrease the cytotoxic activity of decidual lymphocytes and block their perforin release in a concentration-dependent manner (9). Furthermore, in vitro experiments have shown that RU486 decreases PIBF mRNA expression in a human leukemia cell line and this anti-progestin can improve survival and quality of life when used in vivo on mice with lymphocytic leukemia $(183,287)$. However, our own studies with women given RU486 treatment during early pregnancy have demonstrated that P4 may broadly suppress antigen-specific memory cytotoxic $\mathrm{T}$ lymphocyte (CTL) responses in peripheral blood (160). At the same time, contrary to previous reports, our flow cytometric data from these patients indicates this effect is not driven by PIBF $(9,272)$. It is possible that there was a lack of PIBF sensitivity in our patient cohort. It is also conceivable that PIBF sensitivity may simply be a property of decidual leukocytes in humans because P4 concentrations are higher in the decidua than peripheral blood (288), by virtue of their proximity to the placenta, which could result in different $\mathrm{P} 4$ response profiles during pregnancy.

\section{CONCLUDING REMARKS}

P4 mediates a series of immune adaptations that preferentially promote continued pregnancy (Figure 3). It achieves this by inducing a Th2 dominant cytokine environment whilst concurrently suppressing pro-inflammatory immune responses. This occurs both systemically and locally at the maternal-fetal interface. Balanced interplay between the neuroendocrine and immune compartments is a key to establishing and regulating these crucial immunomodulatory changes during a healthy pregnancy. Functional P4 withdrawal occurs as a consequence of a predetermined gestational length, which can be altered by immune cell activity from the mother, the neonate or the maternal-fetal interface to drive the onset of labor. For most of pregnancy, $\mathrm{P} 4$ has to both suppress maternal responses to fetal antigens and prevent overt inflammatory responses to harmful environmental stimuli encountered by the mother. Disruption to P4 signaling that promotes the progression of pregnancy can lead to the mistiming of childbirth, which often bears adverse consequences for the health of both the mother and fetus. The design of novel effective therapies for obstetric complications will be dependent on future research that further elucidates the mechanistic details of the P4 signaling network, specifically with regards to interactions between the immune and reproductive systems that occur during both healthy and pathological pregnancies.

\section{AUTHOR CONTRIBUTIONS}

All authors listed have made a substantial, direct and intellectual contribution to the work, and approved it for publication.

\section{FUNDING}

NMS, PFL, and MRJ are funded by grants from Borne (charity number 1167073), and NI is funded by grants from the MRC (Grant number G0501957), Westminster Medical School Research Trust (247808), and St Stephen's AIDS Trust (1134163).

\section{ACKNOWLEDGMENTS}

Infrastructure support was provided by the National Institute for Health Research (NIHR) and Imperial Biomedical Research Centre (BRC). 


\section{REFERENCES}

1. Tibbetts TA, DeMayo F, Rich S, Conneely OM, O'Malley BW. Progesterone receptors in the thymus are required for thymic involution during pregnancy and for normal fertility. Proc Natl Acad Sci USA. (1999) 96:12021-6. doi: $10.1073 /$ pnas. 96.21 .12021

2. Piccinni MP, Giudizi MG, Biagiotti R, Beloni L, Giannarini L, Sampognaro S, et al. Progesterone favors the development of human Thelper cells producing Th2-type cytokines and promotes both IL-4 production and membrane CD30 expression in established Th1 cell clones. J Immunol. (1995) $155: 128-33$.

3. Mesiano S, Chan EC, Fitter JT, Kwek K, Yeo G, Smith R. Progesterone withdrawal and estrogen activation in human parturition are coordinated by progesterone receptor A expression in the myometrium. J Clin Endocrinol Metab. (2002) 87:2924-30. doi: 10.1210/jcem.87.6.8609

4. Tan H, Yi L, Rote NS, Hurd WW, Mesiano S. Progesterone receptor$\mathrm{A}$ and $-\mathrm{B}$ have opposite effects on proinflammatory gene expression in human myometrial cells: implications for progesterone actions in human pregnancy and parturition. J Clin Endocrinol Metab. (2012). 97:E719-30. doi: 10.1210/jc.2011-3251

5. Hudic I, Fatusic Z, Szekeres-Bartho J, Balic D, Polgar B, Ljuca D, et al. Progesterone-induced blocking factor and cytokine profile in women with threatened pre-term delivery. Am J Reprod Immunol. (2009) 61:330-7. doi: 10.1111/j.1600-0897.2009.00699.x

6. Hudic I, Szekeres-Bartho J, Fatusic Z, Stray-Pedersen B, Dizdarevic-Hudic L, Latifagic A, et al. Dydrogesterone supplementation in women with threatened preterm delivery-the impact on cytokine profile, hormone profile, and progesterone-induced blocking factor. J Reprod Immunol. (2011) 92:103-7. doi: 10.1016/j.jri.2011.08.006

7. Lissauer D, Eldershaw SA, Inman CF, Coomarasamy A, Moss PA, Kilby MD. Progesterone promotes maternal-fetal tolerance by reducing human maternal T-cell polyfunctionality and inducing a specific cytokine profile. Eur J Immunol. (2015) 45:2858-72. doi: 10.1002/eji.201445404

8. Miyaura H, Iwata M. Direct and indirect inhibition of Th1 development by progesterone and glucocorticoids. J Immunol. (2002) 168:1087-94. doi: 10.4049/jimmunol.168.3.1087

9. Laskarin G, Tokmadzic VS, Strbo N, Bogovic T, Szekeres-Bartho J, Randic L, et al. Progesterone induced blocking factor (PIBF) mediates progesterone induced suppression of decidual lymphocyte cytotoxicity. Am J Reprod Immunol. (2002) 48:201-9. doi: 10.1034/j.1600-0897.2002. 01133.x

10. Arck P, Hansen PJ, Mulac Jericevic B, Piccinni MP, Szekeres-Bartho J. Progesterone during pregnancy: endocrine-immune cross talk in mammalian species and the role of stress. Am J Reprod Immunol. (2007) 58:268-79. doi: 10.1111/j.1600-0897.2007.00512.x

11. Stjernholm YV. Progesterone in human pregnancy and parturition. In: Dubey PR, editor. Sex Hormones. InTech (2012), p. 100-14.

12. Chernecky CC, Berger BJ. Laboratory Tests and Diagnostic Procedures. 6th $E d n$. St Louis, MO: Elsevier Saunders (2013), p. 908-9.

13. Migale R, MacIntyre DA, Cacciatore S, Lee YS, Hagberg H, Herbert BR, et al. Modeling hormonal and inflammatory contributions to preterm and term labor using uterine temporal transcriptomics. BMC Med. (2016) 14:86. doi: 10.1186/s12916-016-0632-4

14. Elovitz MA, Mrinalini C. Animal models of preterm birth. Trends Endocrin Met. 15:479-87.

15. Mitchell BF, Taggart MJ. Are animal models relevant to key aspects of human parturition? Am J Physiol Regul Integr Comp Physiol. (2009) 297:R525-45. doi: 10.1152/ajpregu.00153.2009

16. Chwalisz K, Stockemann K, Fuhrmann U, Fritzemeier KH, Einspanier A, Garfield RE. Mechanism of action of antiprogestins in the pregnant uterus. Ann NY Acad Sci. (1995) 761:202-23. doi: 10.1111/j.1749-6632.1995.tb31380.x

17. Martin N, Hoftmann T, Politt E, Hoppen HO, Sohr M, Gunzel-Apel AR, et al. Morphological examination of the corpora lutea from pregnant bitches treated with different abortifacient regimes. Reprod Domest Anim. (2009) 44(Suppl. 2):185-9. doi: 10.1111/j.1439-0531.2009.01430.x

18. Csapo A. Progesterone block. Am J Anat. (1956) 98:273-91. doi: 10.1002/aja.1000980206
19. Csapo AI, Pinto-Dantas CA. The effect of progesterone on the human uterus. Proc Natl Acad Sci USA. (1965) 54:1069-76. doi: 10.1073/pnas.54.4.1069

20. Csapo AI, Pulkkinen MO, Kaihola HL. The effect of luteectomy-induced progesterone-withdrawal on the oxytocin and prostaglandin response of the first trimester pregnant human uterus. Prostaglandins. (1973) 4:421-9. doi: 10.1016/0090-6980(73)90030-0

21. Csapo AI, Pohanka O, Kaihola HL. Progesterone deficiency and premature labour. Br Med J. (1974) 1:137-40. doi: 10.1136/bmj.1.5899.137

22. Edey LF, Georgiou H, O’Dea KP, Mesiano S, Herbert BR, Lei K, et al. Progesterone, the maternal immune system and the onset of parturition in the mouse. Biol Reprod. (2018) 98:376-95. doi: 10.1093/biolre/iox146

23. Merlino AA, Welsh TN, Tan H, Yi LJ, Cannon V, Mercer BM, et al. Nuclear progesterone receptors in the human pregnancy myometrium: evidence that parturition involves functional progesterone withdrawal mediated by increased expression of progesterone receptor-A. J Clin Endocrinol Metab. (2007) 92:1927-33. doi: 10.1210/jc.2007-0077

24. Merlino A, Welsh T, Erdonmez T, Madsen G, Zakar T, Smith R, et al. Nuclear progesterone receptor expression in the human fetal membranes and decidua at term before and after labor. Reprod Sci. (2009) 16:357-63. doi: 10.1177/1933719108328616

25. Langmia IM, Apalasamy YD, Omar SZ, Mohamed Z. Progesterone receptor (PGR) gene polymorphism is associated with susceptibility to preterm birth. BMC Med Genet. (2015) 16:63. doi: 10.1186/s12881-015-0202-1

26. Su MT, Lin SH, Chen YC. Association of sex hormone receptor gene polymorphisms with recurrent pregnancy loss: a systematic review and meta-analysis. Fertil Steril. (2011) 96:1435-44. doi: 10.1016/j.fertnstert.2011.09.030

27. Szekeres-Bartho J, Kilar F, Falkay G, Csernus V, Török A, Pacsa AS. The mechanism of the inhibitory effect of progesterone on lymphocyte cytotoxicity: I. progesterone-treated lymphocytes release a substance inhibiting cytotoxicity and prostaglandin synthesis. Am J Reprod Immunol Microbiol. (1985) 9:15-8. doi: 10.1111/j.1600-0897.1985.tb00334.x

28. van Kaam KJ, Romano A, Schouten JP, Dunselman GA, Groothuis PG. Progesterone receptor polymorphism $+331 \mathrm{G} / \mathrm{A}$ is associated with a decreased risk of deep infiltrating endometriosis. Hum Reprod. (2007) 22:129-35. doi: 10.1093/humrep/del325

29. Szekeres-Bartho J, Barakonyi A, Par G, Polgar B, Palkovics T, Szereday L. Progesterone as an immunomodulatory molecule. Int Immunopharmacol. (2001) 6:1037-48. doi: 10.1016/S1567-5769(01)00035-2

30. Polgar B, Nagy E, Miko E, Varga P, Szekeres-Bartho J. Urinary progesterone-induced blocking factor concentration is related to pregnancy outcome. Biol Reprod. (2004) 71:1699-705. doi: 10.1095/biolreprod. 104.030437

31. Romero R, Conde-Agudelo A, Da Fonseca E, O’Brien JM, Cetingoz E, Creasy $\mathrm{GW}$, et al. Vaginal progesterone for preventing preterm birth and adverse perinatal outcomes in singleton gestations with a short cervix: a metaanalysis of individual patient data. Am J Obstet Gynecol. (2018) 218:161-80. doi: 10.1016/j.ajog.2017.11.576

32. Dodd JM, Jones L, Flenady V, Cincotta R, Crowther CA. Prenatal administration of progesterone for preventing preterm birth in women considered to be at risk of preterm birth. Cochrane $D b$ Syst Rev. 2013:CD004947.

33. Romero R, Nicolaides KH, Conde-Agudelo A, O'Brien J M, Cetingoz E, $\mathrm{Da}$ Fonseca E, et al. Vaginal progesterone decreases preterm birth $</=$ 34 weeks of gestation in women with a singleton pregnancy and a short cervix: an updated meta-analysis including data from the OPPTIMUM study. Ultrasound Obstet Gynecol. (2016) 48:308-17.

34. Fonseca EB, Celik E, Parra M, Singh M, Nicolaides KH, Thornton S, et al. Progesterone and the risk of preterm birth among women with a short cervix. N Engl J Med. (2007) 357:462-9. doi: 10.1056/NEJMoa 067815

35. Hassan SS, Romero R, Vidyadhari D, Fusey S, Baxter JK, Khandelwal $M$, et al. Vaginal progesterone reduces the rate of preterm birth in women with a sonographic short cervix: a multicenter, randomized, doubleblind, placebo-controlled trial. Ultrasound Obstet Gynecol. (2011) 38:18-31. doi: 10.1002/uog. 9017

36. Schuit E, Stock S, Rode L, Rouse DJ, Lim AC, Norman JE, et al. Effectiveness of progestogens to improve perinatal outcome in twin pregnancies: 
an individual participant data meta-analysis. BJOG. (2015) 122:27-37. doi: 10.1111/1471-0528.13032

37. Wood S, Ross S, Tang S, Miller L, Sauve R, Brant R. Vaginal progesterone to prevent preterm birth in multiple pregnancy: a randomized controlled trial. J Perinat Med. (2012) 40:593-9. doi: 10.1515/jpm-2012-0057

38. Norman JE, Mackenzie F, Owen P, Mactier H, Hanretty K, Cooper $\mathrm{S}$, et al. Progesterone for the prevention of preterm birth in twin pregnancy (STOPPIT): a randomised, double-blind, placebocontrolled study and meta-analysis. Lancet. (2009) 373:2034-40. doi: 10.1016/S0140-6736(09)60947-8

39. Romero R, Nicolaides KH, Conde-Agudelo A, O’Brien JM, Cetingoz E, $\mathrm{Da}$ Fonseca E, et al. Vaginal progesterone decreases preterm birth $\leq 34$ weeks of gestation in women with a singleton pregnancy and a short cervix: an updated meta-analysis including data from the OPPTIMUM study. Ultrasound Obstet Gynecol. (2016) 48:308-17. doi: 10.1002/uog.15953

40. Coomarasamy A, Williams H, Truchanowicz E, Seed PT, Small R, Quenby S, et al. PROMISE: first-trimester progesterone therapy in women with a history of unexplained recurrent miscarriages - a randomised, double-blind, placebo-controlled, international multicentre trial and economic evaluation. Health Technol Assess. (2016) 20:1-92. doi: 10.3310/hta20410

41. Ciampaglia W, Cognigni GE. Clinical use of progesterone in infertility and assisted reproduction. Acta Obstet Gynecol Scand. (2015) 94(Suppl. 161):17-27. doi: 10.1111 /aogs.12770

42. Wahabi HA, Fayed AA, Esmaeil SA, Bahkali KH. Progestogen for treating threatened miscarriage. Cochrane Database Syst Rev. (2018) 8:CD005943. doi: 10.1002/14651858.CD005943.pub5

43. Norman JE, Bennett P. Preterm birth prevention-Time to PROGRESS beyond progesterone. PLoS Med. (2017) 14:e1002391. doi: 10.1371/journal.pmed.1002391

44. Wen DX, Xu YF, Mais DE, Goldman ME, McDonnell DP. The A and $\mathrm{B}$ isoforms of the human progesterone receptor operate through distinct signaling pathways within target cells. Mol Cell Biol. (1994) 14:8356-64. doi: $10.1128 / \mathrm{MCB} .14 .12 .8356$

45. Leonhardt SA, Boonyaratanakornkit V, Edwards DP. Progesterone receptor transcription and non-transcription signaling mechanisms. Steroids. (2003) 68:761-70. doi: 10.1016/S0039-128X(03)00129-6

46. Kastner P, Krust A, Turcotte B, Stropp U, Tora L, Gronemeyer H, et al. Two distinct estrogen-regulated promoters generate transcripts encoding the two functionally different human progesterone receptor forms A and B. EMBO J. (1990) 9:1603-14. doi: 10.1002/j.1460-2075.1990. tb08280.x

47. Mesiano S. Myometrial progesterone responsiveness. Semin Reprod Med. (2007) 25:5-13. doi: 10.1055/s-2006-956771

48. Boonyaratanakornkit V, Bi Y, Rudd M, Edwards DP. The role and mechanism of progesterone receptor activation of extra-nuclear signaling pathways in regulating gene transcription and cell cycle progression. Steroids. (2008) 73:922-8. doi: 10.1016/j.steroids.2008.01.010

49. Abdel-Hafiz HA, Horwitz KB. Post-translational modifications of the progesterone receptors. J Steroid Biochem Mol Biol. (2014) 140:80-9. doi: 10.1016/j.jsbmb.2013.12.008

50. Sleiter N, Pang Y, Park C, Horton TH, Dong J, Thomas P, et al. Progesterone receptor A (PRA) and PRB-independent effects of progesterone on gonadotropin-releasing hormone release. Endocrinology. (2009) 150:383344. doi: 10.1210/en.2008-0774

51. Shibata H, Spencer TE, Onate SA, Jenster G, Tsai SY, Tsai MJ, et al. Role of co-activators and co-repressors in the mechanism of steroid/thyroid receptor action. Recent Prog Horm Res. (1997) 52:141-64; discussion 64-5.

52. Giangrande PH, Kimbrel EA, Edwards DP, McDonnell DP. The opposing transcriptional activities of the two isoforms of the human progesterone receptor are due to differential cofactor binding. Mol Cell Biol. (2000) 20:3102-15. doi: 10.1128/MCB.20.9.3102-3115.2000

53. Liu Z, Auboeuf D, Wong JM, Chen JD, Tsai SY, Tsai MJ, et al. Coactivator/corepressor ratios modulate PR-mediated transcription by the selective receptor modulator RU486. Proc Natl Acad Sci USA. (2002) 99:7940-4. doi: 10.1073/pnas.122225699

54. Sartorius CA, Melville MY, Hovland AR, Tung L, Takimoto GS, Horwitz $\mathrm{KB}$. A third transactivation function (AF3) of human progesterone receptors located in the unique N-terminal segment of the B-isoform. Mol Endocrinol. (1994) 8:1347-60.

55. Mesiano S, Wang Y, Norwitz ER. Progesterone receptors in the human pregnancy uterus: do they hold the key to birth timing? Reprod Sci. (2011) 18:6-19. doi: 10.1177/1933719110382922

56. Gadkar-Sable S, Shah C, Rosario G, Sachdeva G, Puri C. Progesterone receptors: various forms and functions in reproductive tissues. Front Biosci. (2005) 10:2118-30. doi: 10.2741/1685

57. Nadeem L, Shynlova O, Matysiak-Zablocki E, Mesiano S, Dong X, Lye S. Molecular evidence of functional progesterone withdrawal in human myometrium. Nat Commun. (2016) 7:11565. doi: 10.1038/ncomms11565

58. Vegeto E, Shahbaz MM, Wen DX, Goldman ME, O’Malley BW, McDonnell DP. Human progesterone receptor A form is a cell- and promoter-specific repressor of human progesterone receptor B function. Mol Endocrinol. (1993) 7:1244-55.

59. Amini P, Wilson R, Wang J, Tan H, Yi L, Koeblitz WK, et al. Progesterone and cAMP synergize to inhibit responsiveness of myometrial cells to proinflammatory/pro-labor stimuli. Mol Cell Endocrinol. (2018). 479:1-11. doi: 10.1016/j.mce.2018.08.005

60. Huse B, Verca SB, Matthey P, Rusconi S. Definition of a negative modulation domain in the human progesterone receptor. Mol Endocrinol. (1998) 12:1334-42. doi: 10.1210/mend.12.9.0164

61. Singhal H, Greene ME, Zarnke AL, Laine M, Al Abosy R, Chang YF, et al. Progesterone receptor isoforms, agonists and antagonists differentially reprogram estrogen signaling. Oncotarget. (2018) 9:4282-300. doi: 10.18632 /oncotarget.21378

62. Dosiou C, Hamilton AE, Pang Y, Overgaard MT, Tulac S, Dong J, et al. Expression of membrane progesterone receptors on human $\mathrm{T}$ lymphocytes and Jurkat cells and activation of G-proteins by progesterone. J Endocrinol. (2008) 196:67-77. doi: 10.1677/JOE-07-0317

63. Ndiaye K, Poole DH, Walusimbi S, Cannon MJ, Toyokawa K, Maalouf SW, et al. Progesterone effects on lymphocytes may be mediated by membrane progesterone receptors. J Reprod Immunol. (2012) 95:15-26. doi: $10.1016 /$ j.jri.2012.04.004

64. Ehring GR, Kerschbaum HH, Eder C, Neben AL, Fanger CM, Khoury $\mathrm{RM}$, et al. A nongenomic mechanism for progesterone-mediated immunosuppression: inhibition of $\mathrm{K}+$ channels, $\mathrm{Ca} 2+$ signaling, and gene expression in T lymphocytes. J Exp Med. (1998) 188:1593-602. doi: 10.1084/jem.188.9.1593

65. Mao G, Wang J, Kang Y, Tai P, Wen J, Zou Q, et al. Progesterone increases systemic and local uterine proportions of CD4+CD25+ Treg cells during midterm pregnancy in mice. Endocrinology. (2010) 151:5477-88. doi: 10.1210/en.2010-0426

66. Szekeres-Bartho J, Szekeres G, Debre P, Autran B, Chaouat G. Reactivity of lymphocytes to a progesterone receptor-specific monoclonal antibody. Cell Immunol. (1990) 125:273-83. doi: 10.1016/0008-8749(90)90083-4

67. Petersen SL, Intlekofer KA, Moura-Conlon PJ, Brewer DN, Del Pino Sans J, Lopez JA. Nonclassical progesterone signalling molecules in the nervous system. J Neuroendocrinol. (2013) 25:991-1001. doi: 10.1111/jne.12060

68. Thomas P, Tubbs C, Garry VF. Progestin functions in vertebrate gametes mediated by membrane progestin receptors (mPRs): identification of mPRalpha on human sperm and its association with sperm motility. Steroids. (2009) 74:614-21. doi: 10.1016/j.steroids.2008.10.020

69. Fernandes MS, Brosens JJ, Gellersen B. Honey, we need to talk about the membrane progestin receptors. Steroids. (2008) 73:942-52. doi: 10.1016/j.steroids.2007.12.004

70. Moussatche P, Lyons TJ. Non-genomic progesterone signalling and its non-canonical receptor. Biochem Soc Trans. (2012) 40:200-4. doi: $10.1042 / B S T 20110638$

71. Krietsch T, Fernandes MS, Kero J, Lösel R, Heyens M, Lam EW, et al. Human homologs of the putative $\mathrm{G}$ protein-coupled membrane progestin receptors (mPRalpha, beta, and gamma) localize to the endoplasmic reticulum and are not activated by progesterone. Mol Endocrinol. (2006) 20:3146-64. doi: 10.1210/me.2006-0129

72. Tokumoto T, Hossain MB, Wang J. Establishment of procedures for studying mPR-interacting agents and physiological roles of mPR. Steroids. (2016) 111:79-83. doi: 10.1016/j.steroids.2016.02.015 
73. Thomas P, Pang Y, Dong J, Groenen P, Kelder J, de Vlieg J, et al. Steroid and G protein binding characteristics of the seatrout and human progestin membrane receptor alpha subtypes and their evolutionary origins. Endocrinology. (2007) 148:705-18. doi: 10.1210/en.2006-0974

74. Karteris E, Zervou S, Pang Y, Dong J, Hillhouse EW, Randeva HS, et al. Progesterone signaling in human myometrium through two novel membrane $G$ protein-coupled receptors: potential role in functional progesterone withdrawal at term. Mol Endocrinol. (2006) 20:1519-34. doi: 10.1210/me.2005-0243

75. Salazar M, Lerma-Ortiz A, Hooks GM, Ashley AK, Ashley RL. Progestinmediated activation of MAPK and AKT in nuclear progesterone receptor negative breast epithelial cells: the role of membrane progesterone receptors. Gene. (2016) 591:6-13. doi: 10.1016/j.gene.2016.06.044

76. Matsuda S, Moriguchi T, Koyasu S, Nishida E. T lymphocyte activation signals for interleukin-2 production involve activation of MKK6-p38 and MKK7-SAPK/JNK signaling pathways sensitive to cyclosporin A. J Biol Chem. (1998) 273:12378-82. doi: 10.1074/jbc.273.20.12378

77. Meyer C, Schmid R, Scriba PC, Wehling M. Purification and partial sequencing of high-affinity progesterone-binding site(s) from porcine liver membranes. Eur J Biochem. (1996) 239:726-31. doi: 10.1111/j.1432-1033.1996.0726u.x

78. Selmin O, Lucier GW, Clark GC, Tritscher AM, Vanden Heuvel JP, Gastel JA, et al. Isolation and characterization of a novel gene induced by $2,3,7,8$ tetrachlorodibenzo-p-dioxin in rat liver. Carcinogenesis. (1996) 17:2609-15. doi: 10.1093/carcin/17.12.2609

79. Wu W, Shi SQ, Huang HJ, Balducci J, Garfield RE. Changes in PGRMC1, a potential progesterone receptor, in human myometrium during pregnancy and labour at term and preterm. Mol Hum Reprod. (2011) 17:233-42. doi: $10.1093 / \mathrm{molehr} /$ gaq096

80. Intlekofer KA, Petersen SL. $17 \beta$-estradiol and progesterone regulate multiple progestin signaling molecules in the anteroventral periventricular nucleus, ventromedial nucleus and sexually dimorphic nucleus of the preoptic area in female rats. Neuroscience. (2011) 176:86-92. doi: 10.1016/j.neuroscience.2010.12.033

81. Zhang Y, Ruan X, Willibald M, Seeger H, Fehm T, Neubauer H, et al. May progesterone receptor membrane component 1 (PGRMC1) predict the risk of breast cancer? Gynecol Endocrinol. (2016) 32:58-60. doi: 10.3109/09513590.2015.1078303

82. Cahill MA. Progesterone receptor membrane component 1: an integrative review. J Steroid Biochem Mol Biol. (2007) 105:16-36. doi: 10.1016/j.jsbmb.2007.02.002

83. Raza FS, Takemori H, Tojo H, Okamoto M, Vinson GP. Identification of the rat adrenal zona fasciculata/reticularis specific protein, inner zone antigen (IZAg), as the putative membrane progesterone receptor. Eur J Biochem. (2001) 268:2141-7. doi: 10.1046/j.1432-1327.2001.02096.x

84. Falkenstein E, Schmieding K, Lange A, Meyer C, Gerdes D, Welsch U, et al. Localization of a putative progesterone membrane binding protein in porcine hepatocytes. Cell Mol Biol. (1998) 44:571-8.

85. Salsano S, Quinonero A, Perez S, Garrido Gomez T, Simon C, Dominguez F. Dynamic expression of PGRMC1 and SERBP1 in human endometrium: an implication in the human decidualization process. Fertil Steril. (2017) 108:832-42e1. doi: 10.1016/j.fertnstert.2017.07.1163

86. Kaluka D, Batabyal D, Chiang BY, Poulos TL, Yeh SR. Spectroscopic and mutagenesis studies of human PGRMC1. Biochemistry. (2015) 54:1638-47. doi: 10.1021/bi501177e

87. Zhang L, Kanda Y, Roberts DJ, Ecker JL, Losel R, Wehling M, et al. Expression of progesterone receptor membrane component 1 and its partner serpine 1 mRNA binding protein in uterine and placental tissues of the mouse and human. Mol Cell Endocrinol. (2008) 287:81-9. doi: 10.1016/j.mce.2008.02.012

88. Peluso JJ, Romak J, Liu X. Progesterone receptor membrane component1 (PGRMC1) is the mediator of progesterone's antiapoptotic action in spontaneously immortalized granulosa cells as revealed by PGRMC1 small interfering ribonucleic acid treatment and functional analysis of PGRMC1 mutations. Endocrinology. (2008) 149:534-43. doi: 10.1210/en.2007-1050

89. Peluso JJ, Pappalardo A. Progesterone regulates granulosa cell viability through a protein kinase G-dependent mechanism that may involve 14-33sigma. Biol Reprod. (2004) 71:1870-8. doi: 10.1095/biolreprod.104.031716
90. Keator CS, Mah K, Slayden OD. Alterations in progesterone receptor membrane component 2 (PGRMC2) in the endometrium of macaques afflicted with advanced endometriosis. Mol Hum Reprod. (2012) 18:308-19. doi: 10.1093/molehr/gas006

91. Areia A, Vale-Pereira S, Alves V, Rodrigues-Santos P, Moura P, Mota-Pinto A. Membrane progesterone receptors in human regulatory $\mathrm{T}$ cells: a reality in pregnancy. BJOG. (2015) 122:1544-50. doi: 10.1111/1471-0528.13294

92. Feng LP, Desravine N, Nazzal M, Pryor K, Murtha A. Characterization of progesterone receptor membrane component 1 in peripheral blood mononuclear cells and plasma during pregnancy. Reprod Sci. (2016) 23:292A. doi: 10.4172/2572-5645. 1000109

93. Kuwabara T, Matsui Y, Ishikawa F, Kondo M. Regulation of T-cell signaling by post-translational modifications in autoimmune disease. Int J Mol Sci. (2018) 19:819. doi: 10.3390/ijms19030819

94. Mani SK, Oyola MG. Progesterone signaling mechanisms in brain and behavior. Front Endocrinol. (2012) 3:7. doi: 10.3389/fendo.2012.00007

95. Grazzini E, Guillon G, Mouillac B, Zingg HH. Inhibition of oxytocin receptor function by direct binding of progesterone. Nature. (1998) 392:509-12. doi: $10.1038 / 33176$

96. Ndiaye K, Poole DH, Pate JL. Expression and regulation of functional oxytocin receptors in bovine T lymphocytes. Biol Reprod. (2008) 78:786-93. doi: 10.1095/biolreprod.107.065938

97. Attardi BJ, Zeleznik A, Simhan H, Chiao JP, Mattison DR, Caritis $\mathrm{SN}$, et al. Comparison of progesterone and glucocorticoid receptor binding and stimulation of gene expression by progesterone, 17alpha hydroxyprogesterone caproate, and related progestins. Am J Obstet Gynecol. (2007) 197:599.e1-7. doi: 10.1016/j.ajog.2007. 05.024

98. Lei K, Chen L, Georgiou EX, Sooranna SR, Khanjani S, Brosens JJ, et al. Progesterone acts via the nuclear glucocorticoid receptor to suppress IL1beta-induced COX-2 expression in human term myometrial cells. PLoS ONE. (2012) 7:e50167. doi: 10.1371/journal.pone.0050167

99. Lei K, Georgiou EX, Chen L, Yulia A, Sooranna SR, Brosens JJ, et al. Progesterone and the repression of myometrial inflammation: the roles of MKP-1 and the AP-1 system. Mol Endocrinol. (2015) 29:1454-67. doi: 10.1210/me.2015-1122

100. Robertson SA, Jin M, Yu D, Moldenhauer LM, Davies MJ, Hull $\mathrm{ML}$, et al. Corticosteroid therapy in assisted reproduction - immune suppression is a faulty premise. Hum Reprod. (2016) 31:2164-73. doi: 10.1093/humrep/dew186

101. Engler JB, Kursawe N, Solano ME, Patas K, Wehrmann S, Heckmann $\mathrm{N}$, et al. Glucocorticoid receptor in $\mathrm{T}$ cells mediates protection from autoimmunity in pregnancy. Proc Natl Acad Sci USA. (2017) 114:E181-90. doi: 10.1073/pnas.1617115114

102. Hierweger AM, Engler JB, Friese MA, Reichardt HM, Lydon J, DeMayo $\mathrm{F}$, et al. Progesterone modulates the T-cell response via glucocorticoid receptor-dependent pathways. Am J Reprod Immunol. (2019) 2:e13084. doi: 10.1111/aji.13084

103. Zhang D, Liu H, Zeng J, Miao X, Huang $\mathrm{W}$, Chen $\mathrm{H}$, et al. Glucocorticoid exposure in early placentation induces preeclampsia in rats via interfering trophoblast development. Gen Comp Endocrinol. (2016) 225:61-70. doi: 10.1016/j.ygcen.2015.09.019

104. Braun T, Meng W, Shang H, Li S, Sloboda DM, Ehrlich L, et al. Early dexamethasone treatment induces placental apoptosis in sheep. Reprod Sci. (2015) 22:47-59. doi: 10.1177/1933719114542028

105. Laloha F, Asiabar NM, Barikani A, Movahed F, Haj Seyed Javadi E. Effect of intravenous dexamethasone on preparing the cervix and labor induction. Acta Med Iran. (2015) 53:568-72. Available online at: http://acta.tums.ac.ir/ index.php/acta/article/view/4295

106. Wang W, Guo C, Zhu P, Lu J, Li W, Liu C, et al. Phosphorylation of STAT3 mediates the induction of cyclooxygenase- 2 by cortisol in the human amnion at parturition. Sci Signal. (2015) 8:ra106. doi: 10.1126/scisignal.aac6151

107. Guyre PM, Munck A. Glucocorticoids A2 - Delves, Peter J. Encyclopedia of Immunology (Second Edition). Oxford: Elsevier (1998) p. 996-1001.

108. Oakley RH, Sar M, Cidlowski JA. The human glucocorticoid receptor beta isoform. Expression, biochemical properties, and putative function. J Biol Chem. (1996) 271:9550-9. doi: 10.1074/jbc.271.16.9550 
109. He B, Cruz-Topete D, Oakley RH, Xiao X, Cidlowski JA. Human glucocorticoid receptor $\beta$ regulates gluconeogenesis and inflammation in mouse liver. Mol Cell Biol. (2015) 36:714-30. doi: 10.1128/MCB.00908-15

110. Lu NZ, Collins JB, Grissom SF, Cidlowski JA. Selective regulation of bone cell apoptosis by translational isoforms of the glucocorticoid receptor. Mol Cell Biol. (2007) 27:7143-60. doi: 10.1128/MCB.00253-07

111. Song IH, Buttgereit F. Non-genomic glucocorticoid effects to provide the basis for new drug developments. Mol Cell Endocrinol. (2006) 246:142-6. doi: $10.1016 /$ j.mce.2005.11.012

112. Nahar J, Rainville JR, Dohanich GP, Tasker JG. Further evidence for a membrane receptor that binds glucocorticoids in the rodent hypothalamus. Steroids. (2016) 114:33-40. doi: 10.1016/j.steroids.2016.05.013

113. Gametchu B. Glucocorticoid receptor-like antigen in lymphoma cell membranes: correlation to cell lysis. Science. (1987) 236:456-61. doi: $10.1126 /$ science. 3563523

114. Orchinik M, Murray TF, Franklin PH, Moore FL. Guanyl nucleotides modulate binding to steroid receptors in neuronal membranes. Proc Natl Acad Sci USA. (1992) 89:3830-4. doi: 10.1073/pnas.89.9.3830

115. Evans SJ, Murray TF, Moore FL. Partial purification and biochemical characterization of a membrane glucocorticoid receptor from an amphibian brain. $J$ Steroid Biochem Mol Biol. (2000) 72:209-21. doi: 10.1016/S0960-0760(00) 00031-5

116. Vitellius G, Fagart J, Delemer B, Amazit L, Ramos N, Bouligand J, et al. Three novel heterozygous point mutations of NR3C1 causing glucocorticoid resistance. Hum Mutat. (2016) 37:794-803. doi: 10.1002/humu.23008

117. Strehl C, Gaber T, Lowenberg M, Hommes DW, Verhaar AP, Schellmann S, et al. Origin and functional activity of the membrane-bound glucocorticoid receptor. Arthritis Rheum. (2011) 63:3779-88. doi: 10.1002/art.30637

118. Bartholome B, Spies CM, Gaber T, Schuchmann S, Berki T, Kunkel D, et al. Membrane glucocorticoid receptors (mGCR) are expressed in normal human peripheral blood mononuclear cells and up-regulated after in vitro stimulation and in patients with rheumatoid arthritis. FASEB J. (2004) 18:70-80. doi: 10.1096/fj.03-0328com

119. Gametchu B, Watson CS. Correlation of membrane glucocorticoid receptor levels with glucocorticoid-induced apoptotic competence using mutant leukemic and lymphoma cells lines. J Cell Biochem. (2002) 87:133-46. doi: $10.1002 /$ jcb. 10288

120. Benes J, Tomankova H, Novakova M, Rohan Z, Kvetnansky R, Myslivecek J. Corticotropin-releasing hormone affects short immobilization stressinduced changes in lung cytosolic and membrane glucocorticoid binding sites. Cell Mol Neurobiol. (2013) 33:503-11. doi: 10.1007/s10571-013-9916-9

121. Strehl C, Gaber T, Jakstadt M, Hahne M, Hoff P, Spies CM, et al. Highsensitivity immunofluorescence staining: a comparison of the liposome procedure and the FASER technique on mGR detection. J Fluoresc. (2013) 23:509-18. doi: 10.1007/s10895-013-1163-4

122. Vernocchi S, Battello N, Schmitz S, Revets D, Billing AM, Turner JD, et al. Membrane glucocorticoid receptor activation induces proteomic changes aligning with classical glucocorticoid effects. Mol Cell Proteomics. (2013) 12:1764-79. doi: 10.1074/mcp.M112.022947

123. Schumacher A, Costa SD, Zenclussen AC. Endocrine factors modulating immune responses in pregnancy. Front Immunol. (2014) 5:196. doi: 10.3389/fimmu.2014.00196

124. Saftlas AF, Rubenstein L, Prater K, Harland KK, Field E, Triche EW. Cumulative exposure to paternal seminal fluid prior to conception and subsequent risk of preeclampsia. J Reprod Immunol. (2014) 101-102:104-10. doi: 10.1016/j.jri.2013.07.006

125. Wira CR, Rodriguez-Garcia M, Patel MV. The role of sex hormones in immune protection of the female reproductive tract. Nat Rev Immunol. (2015) 15:217-30. doi: 10.1038/nri3819

126. Wira CR, Rodriguez-Garcia M, Shen Z, Patel M, Fahey JV. The role of sex hormones and the tissue environment in immune protection against HIV in the female reproductive tract. Am J Reprod Immunol. (2014) 72:171-81. doi: $10.1111 /$ aji.12235

127. Kersh EN, Henning T, Vishwanathan SA, Morris M, Butler K, Adams $\mathrm{DR}$, et al. SHIV susceptibility changes during the menstrual cycle of pigtail macaques. J Med Primatol. (2014) 43:310-6. doi: 10.1111/jmp. 12124
128. Scholz C, Toth B, Brunnhuber R, Rampf E, Weissenbacher T, Santoso L, et al. Glycodelin A induces a tolerogenic phenotype in monocytederived dendritic cells in vitro. Am J Reprod Immunol. (2008) 60:501-12. doi: $10.1111 / j .1600-0897.2008 .00647 . x$

129. Ochanuna Z, Geiger-Maor A, Dembinsky-Vaknin A, Karussis D, Tykocinski $\mathrm{ML}$, Rachmilewitz J. Inhibition of effector function but not $\mathrm{T}$ cell activation and increase in FoxP3 expression in T cells differentiated in the presence of PP14. PLoS ONE. (2010) 5:e12868. doi: 10.1371/journal.pone. 0012868

130. Hausermann HM, Donnelly KM, Bell SC, Verhage HG, Fazleabas AT. Regulation of the glycosylated beta-lactoglobulin homolog, glycodelin [placental protein 14:(PP14)] in the baboon (Papio anubis) uterus. J Clin Endocrinol Metab. (1998) 83:1226-33.

131. Okamoto N, Uchida A, Takakura K, Kariya Y, Kanzaki H, Riittinen L, et al. Suppression by human placental protein 14 of natural killer cell activity. Am J Reprod Immunol. (1991) 26:137-42. doi: 10.1111/j.1600-0897.1991.tb00713.x

132. Mishan-Eisenberg G, Borovsky Z, Weber MC, Gazit R, Tykocinski ML, Rachmilewitz J. Differential regulation of Th1/Th2 cytokine responses by placental protein 14. J Immunol. (2004) 173:5524-30. doi: 10.4049/jimmunol.173.9.5524

133. Lee CL, Lam KK, Koistinen H, Seppala M, Kurpisz M, Fernandez N, et al. Glycodelin-A as a paracrine regulator in early pregnancy. J Reprod Immunol. (2011) 90:29-34. doi: 10.1016/j.jri.2011.04.007

134. Massagué J, Attisano L, Wrana JL. The TGF-beta family and its composite receptors. Trends Cell Biol. (1994) 4:172-8. doi: 10.1016/0962-8924(94)90202-X

135. de Caestecker M. The transforming growth factor-beta superfamily of receptors. Cytokine Growth Factor Rev. (2004) 15:1-11. doi: 10.1016/j.cytogfr.2003.10.004

136. Hall BE, Wankhade UD, Konkel JE, Cherukuri K, Nagineni CN, Flanders KC, et al. Transforming growth factor-beta3 (TGF-beta3) knock-in ameliorates inflammation due to TGF-betal deficiency while promoting glucose tolerance. J Biol Chem. (2013) 288:32074-92. doi: 10.1074/jbc.M113.480764

137. Pelton RW, Saxena B, Jones M, Moses HL, Gold LI. Immunohistochemical localization of TGF beta 1, TGF beta 2 , and TGF beta 3 in the mouse embryo: expression patterns suggest multiple roles during embryonic development. $J$ Cell Biol. (1991) 115:1091-105. doi: 10.1083/jcb.115.4.1091

138. Lala PK, Hamilton GS. Growth factors, proteases and protease inhibitors in the maternal-fetal dialogue. Placenta. (1996) 17:545-55. doi: 10.1016/S0143-4004(96)80071-3

139. Schilling B, Yeh J. Transforming growth factor-beta(1), -beta(2), -beta(3) and their type I and II receptors in human term placenta. Gynecol Obstet Invest. (2000) 50:19-23. doi: 10.1159/000010272

140. Graham CH, Lysiak JJ, McCrae KR, Lala PK. Localization of transforming growth factor-beta at the human fetal-maternal interface: role in trophoblast growth and differentiation. Biol Reprod. (1992) 46:561-72. doi: 10.1095/biolreprod46.4.561

141. Joly AL, Liu S, Dahlberg CI, Mailer RK, Westerberg LS, Andersson J. Foxp3 lacking exons 2 and 7 is unable to confer suppressive ability to regulatory $\mathrm{T}$ cells in vivo. J Autoimmun. (2015) 63:23-30. doi: 10.1016/j.jaut.2015.06.009

142. Chen W, Jin W, Hardegen N, Lei KJ, Li L, Marinos N, et al. Conversion of peripheral $\mathrm{CD} 4+\mathrm{CD} 25$ - naive $\mathrm{T}$ cells to $\mathrm{CD} 4+\mathrm{CD} 25+$ regulatory $\mathrm{T}$ cells by TGF-beta induction of transcription factor Foxp3. J Exp Med. (2003) 198:1875-86. doi: 10.1084/jem.20030152

143. Sambucci M, Gargano F, De Rosa V, De Bardi M, Picozza M, Placido R, et al. FoxP3 isoforms and PD-1 expression by T regulatory cells in multiple sclerosis. Sci Rep. (2018) 8:3674. doi: 10.1038/s41598-018-21861-5

144. Rudensky AY. Regulatory T cells and Foxp3. Immunol Rev. (2011) 241:260-8. doi: 10.1111/j.1600-065X.2011.01018.x

145. Faunce DE, Terajewicz A, Stein-Streilein J. Cutting edge: in vitro-generated tolerogenic APC induce CD8+ T regulatory cells that can suppress ongoing experimental autoimmune encephalomyelitis. J Immunol. (2004) 172:19915. doi: 10.4049/jimmunol.172.4.1991

146. Coronel MF, Raggio MC, Adler NS, De Nicola AF, Labombarda F, González SL. Progesterone modulates pro-inflammatory cytokine expression profile after spinal cord injury: Implications for neuropathic pain. J Neuroimmunol. (2016) 292:85-92. doi: 10.1016/j.jneuroim.2016.01.011 
147. Xue XT, Kou XX, Li CS, Bi RY, Meng Z, Wang XD, et al. Progesterone attenuates temporomandibular joint inflammation through inhibition of NF-кB pathway in ovariectomized rats. Sci Rep. (2017) 7:15334. doi: 10.1038/s41598-017-15285-w

148. Lei B, Mace B, Dawson HN, Warner DS, Laskowitz DT, James ML. Antiinflammatory effects of progesterone in lipopolysaccharide-stimulated BV-2 microglia. PLoS ONE. (2014) 9:e103969. doi: 10.1371/journal.pone.0103969

149. You X, Liu J, Xu C, Liu W, Zhu X, Li Y, et al. Corticotropin-releasing hormone $(\mathrm{CRH})$ promotes inflammation in human pregnant myometrium: the evidence of CRH initiating parturition? J Clin Endocrinol Metab. (2014) 99:E199-208. doi: 10.1210/jc.2013-3366

150. Wu SP, DeMayo FJ. Progesterone receptor signaling in uterine myometrial physiology and preterm birth. Curr Top Dev Biol. (2017) 125:171-90. doi: 10.1016/bs.ctdb.2017.03.001

151. Shynlova O, Tsui P, Jaffer S, Lye SJ. Integration of endocrine and mechanical signals in the regulation of myometrial functions during pregnancy and labour. Eur J Obstet Gynecol Reprod Biol. (2009) 144(Suppl. 1):S2-10. doi: 10.1016/j.ejogrb.2009.02.044

152. Vrachnis N, Karavolos S, Iliodromiti Z, Sifakis S, Siristatidis C, Mastorakos $\mathrm{G}$, et al. Review: impact of mediators present in amniotic fluid on preterm labour. In Vivo. (2012) 26:799-812.

153. Vrachnis N, Malamas FM, Sifakis S, Tsikouras P, Iliodromiti Z. Immune aspects and myometrial actions of progesterone and CRH in labor. Clin Dev Immunol. (2012) 2012:937618. doi: 10.1155/2012/937618

154. Yuan Y, Shimizu I, Shen M, Aoyagi E, Takenaka H, Itagaki T, et al. Effects of estradiol and progesterone on the proinflammatory cytokine production by mononuclear cells from patients with chronic hepatitis C. World J Gastroenterol. (2008) 14:2200-7. doi: 10.3748/wjg.14.2200

155. Wu Y, Strawn E, Basir Z, Halverson G, Guo SW. Promoter hypermethylation of progesterone receptor isoform B (PR-B) in endometriosis. Epigenetics. (2006) 1:106-11. doi: 10.4161/epi.1.2.2766

156. Okabe H, Makino S, Kato K, Matsuoka K, Seki H, Takeda S. The effect of progesterone on genes involved in preterm labor. J Reprod Immunol. (2014) 104-105:80-91. doi: 10.1016/j.jri.2014.03.008

157. Migale R, Herbert BR, Lee YS, Sykes L, Waddington SN, Peebles D, et al. Specific lipopolysaccharide serotypes induce differential maternal and neonatal inflammatory responses in a murine model of preterm labor. Am J Pathol. (2015) 185:2390-401. doi: 10.1016/j.ajpath.2015. 05.015

158. Furcron AE, Romero R, Plazyo O, Unkel R, Xu Y, Hassan SS, et al. Vaginal progesterone, but not $17 \alpha$-hydroxyprogesterone caproate, has antiinflammatory effects at the murine maternal-fetal interface. Am J Obstet Gynecol. (2015) 213:846.e1-19. doi: 10.1016/j.ajog.2015.08.010

159. Szekeres-Bartho J, Polgar B. PIBF: the double edged sword. pregnancy and tumor. Am J Reprod Immunol. (2010) 64:77-86. doi: 10.1111/j.1600-0897.2010.00833.x

160. Shah NM, Imami N, Johnson MR. Progesterone modulation of pregnancy-related immune responses. Front Immunol. (2018) 9:1293. doi: 10.3389/fimmu.2018.01293

161. Truong HM, Sim MS, Dillon M, Uittenbogaart CH, Dickover R, Plaeger $\mathrm{SF}$, et al. Correlation of immune activation during late pregnancy and early postpartum with increases in plasma HIV RNA, CD4/CD8 T cells, and serum activation markers. Clin Vaccine Immunol. (2010) 17:2024-8. doi: 10.1128/CVI.00088-10

162. Tilburgs T, Schonkeren D, Eikmans M, Nagtzaam NM, Datema G, Swings $\mathrm{GM}$, et al. Human decidual tissue contains differentiated CD8+ effectormemory T cells with unique properties. J Immunol. (2012) 185:4470-7. doi: 10.4049/jimmunol.0903597

163. Yellon SM. Contributions to the dynamics of cervix remodeling prior to term and preterm birth. Biol Reprod. (2017) 96:13-23. doi: 10.1095/biolreprod.116.142844

164. Haluska GJ, Stanczyk FZ, Cook MJ, Novy MJ. Temporal changes in uterine activity and prostaglandin response to RU486 in rhesus macaques in late gestation. Am J Obstet Gynecol. (1987) 157:1487-95. doi: 10.1016/S0002-9378(87)80249-1

165. Beck CA, Weigel NL, Moyer ML, Nordeen SK, Edwards DP. The progesterone antagonist RU486 acquires agonist activity upon stimulation of cAMP signaling pathways. Proc Natl Acad Sci USA. (1993) 90:4441-5. doi: $10.1073 /$ pnas.90.10.4441

166. Jackson TA, Richer JK, Bain DL, Takimoto GS, Tung L, Horwitz KB. The partial agonist activity of antagonist-occupied steroid receptors is controlled by a novel hinge domain-binding coactivator L7/SPA and the corepressors N-CoR or SMRT. Mol Endocrinol. (1997) 11:693-705. doi: 10.1210/mend.11.6.0004

167. Raaijmakers HCA, Versteegh JE, Uitdehaag JCM. The X-ray structure of RU486 bound to the progesterone receptor in a destabilized agonistic conformation. J Biol Chem. (2009) 284:19572-9. doi: 10.1074/jbc.M109.007872

168. Meyer ME, Pornon A, Ji JW, Bocquel MT, Chambon P, Gronemeyer H. Agonistic and antagonistic activities of Ru486 on the functions of the human progesterone-receptor. EMBO J. (1990) 9:3923-32. doi: 10.1002/j.1460-2075.1990.tb07613.x

169. Kokenyesi R, Armstrong LC, Agah A, Artal R, Bornstein P. Thrombospondin 2 deficiency in pregnant mice results in premature softening of the uterine cervix. Biol Reprod. (2004) 70:385-90. doi: 10.1095/biolreprod.102. 014704

170. Tan XJ, Lang JH, Zheng WM, Leng JH, Zhu L. Ovarian steroid hormones differentially regulate thrombospondin-1 expression in cultured endometrial stromal cells: implications for endometriosis. Fertil Steril. (2010) 93:328-31. doi: 10.1016/j.fertnstert.2009.06.060

171. Yellon SM, Burns AE, See JL, Lechuga TJ, Kirby MA. Progesterone withdrawal promotes remodeling processes in the nonpregnant mouse cervix. Biol Reprod. (2009) 81:1-6. doi: 10.1095/biolreprod.108. 074997

172. Yellon SM, Dobyns AE, Beck HL, Kurtzman JT, Garfield RE, Kirby MA. Loss of progesterone receptor-mediated actions induce preterm cellular and structural remodeling of the cervix and premature birth. PLOS ONE. (2013) 8:e81340. doi: 10.1371/journal.pone.0081340

173. Holt R, Timmons BC, Akgul Y, Akins ML, Mahendroo M. The molecular mechanisms of cervical ripening differ between term and preterm birth. Endocrinology. (2011) 152:1036-46. doi: 10.1210/en.2010-1105

174. Hunter PJ, Sheikh S, David AL, Peebles DM, Klein N. Cervical leukocytes and spontaneous preterm birth. J Reprod Immunol. (2016) 113:42-9. doi: 10.1016/j.jri.2015.11.002

175. Critchfield AS, Yao G, Jaishankar A, Friedlander RS, Lieleg O, Doyle PS, et al. Cervical mucus properties stratify risk for preterm birth. PLOS ONE. (2013) 8:e69528. doi: 10.1371/journal.pone.0069528

176. Buyon JP, Korchak HM, Rutherford LE, Ganguly M, Weissmann G. Female hormones reduce neutrophil responsiveness in vitro. Arthritis Rheum. (1984) 27:623-30. doi: 10.1002/art.1780270604

177. Nadkarni S, Smith J, Sferruzzi-Perri AN, Ledwozyw A, Kishore M, Haas $\mathrm{R}$, et al. Neutrophils induce proangiogenic $\mathrm{T}$ cells with a regulatory phenotype in pregnancy. Proc Natl Acad Sci USA. (2016) 113:E8415-24. doi: 10.1073/pnas.1611944114

178. Butts CL, Shukair SA, Duncan KM, Bowers E, Horn C, Belyavskaya E, et al. Progesterone inhibits mature rat dendritic cells in a receptor-mediated fashion. Int Immunol. (2007) 19:287-96. doi: 10.1093/intimm/dxl145

179. Blois SM, Kammerer U, Alba Soto C, Tometten MC, Shaikly V, Barrientos G, et al. Dendritic cells: key to fetal tolerance? Biol Reprod. (2007) 77:590-8. doi: 10.1095/biolreprod.107.060632

180. Marguti I, Yamamoto GL, da Costa TB, Rizzo LV, de Moraes LV. Expansion of CD4+ CD25+ Foxp3 $+\mathrm{T}$ cells by bone marrow-derived dendritic cells. Immunology. (2009) 127:50-61. doi: 10.1111/j.1365-2567.2008. 02927.x

181. Huijbregts RP, Michel KG, Hel Z. Effect of progestins on immunity: medroxyprogesterone but not norethisterone or levonorgestrel suppresses the function of $\mathrm{T}$ cells and pDCs. Contraception. (2014) 90:123-9. doi: 10.1016/j.contraception.2014.02.006

182. Ito T, Amakawa R, Inaba M, Ikehara S, Inaba K, Fukuhara S. Differential regulation of human blood dendritic cell subsets by IFNs. J Immunol. (2001) 166:2961-9. doi: 10.4049/jimmunol.166.5.2961

183. Srivastava MD, Thomas A, Srivastava BI, Check JH. Expression and modulation of progesterone induced blocking factor (PIBF) and innate immune factors in human leukemia cell lines by 
progesterone and mifepristone. Leuk Lymphoma. (2007) 48:1610-7. doi: 10.1080/10428190701471999

184. Schatz F, Kayisli UA, Vatandaslar E, Ocak N, Guller S, Abrahams VM, et al. Toll-like receptor 4 expression in decidual cells and interstitial trophoblasts across human pregnancy. Am J Reprod Immunol. (2012). 68:146-53. doi: 10.1111/j.1600-0897.2012.01148.x

185. Ziegler SM, Feldmann CN, Hagen SH, Richert L, Barkhausen T, Goletzke $\mathrm{J}$, et al. Innate immune responses to toll-like receptor stimulation are altered during the course of pregnancy. J Reprod Immunol. (2018) 128:30-7. doi: 10.1016/j.jri.2018.05.009

186. Aflatoonian R, Tuckerman E, Elliott SL, Bruce C, Aflatoonian A, Li TC, et al. Menstrual cycle-dependent changes of Toll-like receptors in endometrium. Hum Reprod. (2007) 22:586-93. doi: 10.1093/humrep/del388

187. Ngcapu S, Masson L, Sibeko S, Werner L, McKinnon LR, Mlisana K, et al. Lower concentrations of chemotactic cytokines and soluble innate factors in the lower female genital tract associated with the use of injectable hormonal contraceptive. J Reprod Immunol. (2015) 110:14-21. doi: $10.1016 /$ j.jri.2015.03.007

188. Godiska R, Chantry D, Raport CJ, Sozzani S, Allavena P, Leviten D, et al. Human macrophage-derived chemokine (MDC), a novel chemoattractant for monocytes, monocyte-derived dendritic cells, and natural killer cells. $J$ Exp Med. (1997) 185:1595-604. doi: 10.1084/jem.185.9.1595

189. Andrew DP, Chang MS, McNinch J, Wathen ST, Rihanek M, Tseng J, et al. STCP-1 (MDC) CC chemokine acts specifically on chronically activated Th2 lymphocytes and is produced by monocytes on stimulation with Th2 cytokines IL-4 and IL-13. J Immunol. (1998) 161:5027-38.

190. Carr MW, Roth SJ, Luther E, Rose SS, Springer TA. Monocyte chemoattractant protein 1 acts as a T-lymphocyte chemoattractant. Proc Natl Acad Sci USA. (1994) 91:3652-6. doi: 10.1073/pnas.91.9.3652

191. Umehara H, Bloom ET, Okazaki T, Nagano Y, Yoshie O, Imai T. Fractalkine in vascular biology: from basic research to clinical disease. Arterioscler Thromb Vasc Biol. (2004) 24:34-40. doi: 10.1161/01.ATV.0000095360.62479.1F

192. Yoneda O, Imai $\mathrm{T}$, Goda $\mathrm{S}$, Inoue $\mathrm{H}$, Yamauchi $\mathrm{A}$, Okazaki $\mathrm{T}$, et al. Fractalkine-mediated endothelial cell injury by NK cells. J Immunol. (2000) 164:4055-62. doi: 10.4049/jimmunol.164.8.4055

193. Cooper AM, Khader SA. IL-12p40: an inherently agonistic cytokine. Trends Immunol. (2007) 28:33-8. doi: 10.1016/j.it.2006.11.002

194. Waldmann TA. The biology of IL-15: implications for cancer therapy and the treatment of autoimmune disorders. J Investig Dermatol Symp Proc. (2013) 16:S28-30. doi: 10.1038/jidsymp.2013.8

195. Matsumoto H, Nasu K, Nishida M, Ito H, Bing S, Miyakawa I. Regulation of proliferation, motility, and contractility of human endometrial stromal cells by platelet-derived growth factor. J Clin Endocrinol Metab. (2005) 90:3560-7. doi: $10.1210 /$ jc. $2004-1918$

196. Zandieh Z, Amjadi F, Ashrafi M, Aflatoonian A, Fazeli A, Aflatoonian R. The effect of estradiol and progesterone on toll like receptor gene expression in a human fallopian tube epithelial cell line. Cell J. (2016) 17:678-91.

197. Flores-Espinosa P, Pineda-Torres M, Vega-Sánchez R, Estrada-Gutiérrez G, Espejel-Nuñez A, Flores-Pliego A, et al. Progesterone elicits an inhibitory effect upon LPS-induced innate immune response in pre-labor human amniotic epithelium. Am J Reprod Immunol. (2014) 71:61-72. doi: $10.1111 /$ aji. 12163

198. Menzies FM, Henriquez FL, Alexander J, Roberts CW. Selective inhibition and augmentation of alternative macrophage activation by progesterone. Immunology. (2011) 134:281-91. doi: 10.1111/j.1365-2567.2011.03488.x

199. Su L, Sun Y, Ma F, Lü P, Huang H, Zhou J. Progesterone inhibits Toll-like receptor 4-mediated innate immune response in macrophages by suppressing NF-kappaB activation and enhancing SOCS1 expression. Immunol Lett. (2009) 125:151-5. doi: 10.1016/j.imlet.2009.07.003

200. Jones LA, Anthony JP, Henriquez FL, Lyons RE, Nickdel MB, Carter KC, et al. Toll-like receptor-4-mediated macrophage activation is differentially regulated by progesterone via the glucocorticoid and progesterone receptors. Immunology. (2008) 125:59-69. doi: 10.1111/j.1365-2567.2008.02820.x

201. Lu J, Reese J, Zhou Y, Hirsch E. Progesterone-induced activation of membrane-bound progesterone receptors in murine macrophage cells. $J$ Endocrinol. (2015) 224:183-94. doi: 10.1530/JOE-14-0470
202. Lee CL, Guo Y, So KH, Vijayan M, Wong VH, Yao Y, et al. Soluble human leukocyte antigen G5 polarizes differentiation of macrophages toward a decidual macrophage-like phenotype. Hum Reprod. (2015) 30:2263-74. doi: 10.1093/humrep/dev196

203. Gustafsson C, Mjösberg J, Matussek A, Geffers R, Matthiesen L, Berg $G$, et al. Gene expression profiling of human decidual macrophages: evidence for immunosuppressive phenotype. PLoS ONE. (2008) 3:e2078. doi: 10.1371/journal.pone.0002078

204. Makita N, Hizukuri Y, Yamashiro K, Murakawa M, Hayashi Y. IL-10 enhances the phenotype of M2 macrophages induced by IL-4 and confers the ability to increase eosinophil migration. Int Immunol. (2015) 27:131-41. doi: 10.1093/intimm/dxu090

205. Mia S, Warnecke A, Zhang XM, Malmström V, Harris RA. An optimized protocol for human M2 macrophages using M-CSF and IL-4/IL-10/TGF- $\beta$ yields a dominant immunosuppressive phenotype. Scand J Immunol. (2014) 79:305-14. doi: 10.1111/sji.12162

206. Chaouat G, Cayol V, Mairovitz V, Dubanchet S. Localization of the Th2 cytokines IL-3, IL-4, IL-10 at the fetomaternal interface during human and murine pregnancy and lack of requirement for Fas/Fas ligand interaction for a successful allogeneic pregnancy. Am J Reprod Immunol. (1999) 42:1-13. doi: 10.1111/j.1600-0897.1999.tb00459.x

207. Martinez FO, Gordon S. The M1 and M2 paradigm of macrophage activation: time for reassessment. F1000Prime Rep. (2014) 6:13. doi: 10.12703/P6-13

208. Roszer T. Understanding the mysterious M2 macrophage through activation markers and effector mechanisms. Mediators Inflamm. (2015) 2015:816460. doi: $10.1155 / 2015 / 816460$

209. Tsai YC, Tseng JT, Wang CY, Su MT, Huang JY, Kuo PL. Medroxyprogesterone acetate drives M2 macrophage differentiation toward a phenotype of decidual macrophage. Mol Cell Endocrinol. (2017) 452:74-83. doi: 10.1016/j.mce.2017.05.015

210. Lu KD, Radom-Aizik S, Haddad F, Zaldivar F, Kraft M, Cooper DM. Glucocorticoid receptor expression on circulating leukocytes differs between healthy male and female adults. J Clin Transl Sci. (2017) 1:108-14. doi: $10.1017 /$ cts. 2016.20

211. Marks MA, Gravitt PE, Burk RD, Studentsov Y, Farzadegan H, Klein SL. Progesterone and 17beta-estradiol enhance regulatory responses to human papillomavirus type 16 virus-like particles in peripheral blood mononuclear cells from healthy women. Clin Vaccine Immunol. (2010) 17:609-17. doi: 10.1128/CVI.00441-09

212. Check JH, Dix E, Sansoucie L. Support for the hypothesis that successful immunotherapy of various cancers can be achieved by inhibiting a progesterone associated immunomodulatory protein. Med Hypotheses. (2009) 72:87-90. doi: 10.1016/j.mehy.2008.05.042

213. Chiu L, Nishimura M, Ishii $Y$, Nieda $M$, Maeshima M, Takedani $Y$, et al. Enhancement of the expression of progesterone receptor on progesterone-treated lymphocytes after immunotherapy in unexplained recurrent spontaneous abortion. Am J Reprod Immunol. (1996) 35:552-7. doi: 10.1111/j.1600-0897.1996.tb00056.x

214. Areia A, Vale-Pereira S, Alves V, Rodrigues-Santos P, Santos-Rosa M, Moura $\mathrm{P}$, et al. Can membrane progesterone receptor alpha on $\mathrm{T}$ regulatory cells explain the ensuing human labour? J Reprod Immunol. (2016) 113:22-6. doi: $10.1016 /$ j.jri.2015.10.002

215. Aristimuno C, Teijeiro R, Valor L, Alonso B, Tejera-Alhambra M, de Andres C, et al. Sex-hormone receptors pattern on regulatory T-cells: clinical implications for multiple sclerosis. Clin Exp Med. (2012) 12:247-55. doi: 10.1007/s10238-011-0172-3

216. Herold MJ, McPherson KG, Reichardt HM. Glucocorticoids in $T$ cell apoptosis and function. Cell Mol Life Sci. (2006) 63:60-72. doi: 10.1007/s00018-005-5390-y

217. Schumacher A, Dauven D, Zenclussen AC. Progesterone-driven local regulatory $\mathrm{T}$ cell induction does not prevent fetal loss in the CBA/JxDBA/2J abortion-prone model. Am J Reprod Immunol. (2017) 77:e12626. doi: $10.1111 /$ aji. 12626

218. Zenclussen AC, Gerlof K, Zenclussen ML, Sollwedel A, Bertoja AZ, Ritter $\mathrm{T}$, et al. Abnormal T-cell reactivity against paternal antigens in spontaneous abortion: adoptive transfer of pregnancy-induced $\mathrm{CD} 4+\mathrm{CD} 25+\mathrm{T}$ 
regulatory cells prevents fetal rejection in a murine abortion model. Am J Pathol. (2005) 166:811-22. doi: 10.1016/S0002-9440(10)62302-4

219. Woidacki K, Meyer N, Schumacher A, Goldschmidt A, Maurer M, Zenclussen AC. Transfer of regulatory $\mathrm{T}$ cells into abortion-prone mice promotes the expansion of uterine mast cells and normalizes early pregnancy angiogenesis. Sci Rep. (2015) 5:13938. doi: 10.1038/srep13938

220. Yin Y, Han X, Shi Q, Zhao Y, He Y. Adoptive transfer of CD4+CD25+ regulatory $\mathrm{T}$ cells for prevention and treatment of spontaneous abortion. Eur J Obstet Gynecol Reprod Biol. (2012) 161:177-81. doi: 10.1016/j.ejogrb.2011.12.023

221. Mjosberg J, Svensson J, Johansson E, Hellstrom L, Casas R, Jenmalm MC, et al. Systemic reduction of functionally suppressive CD4dimCD25highFoxp3+ Tregs in human second trimester pregnancy is induced by progesterone and 17beta-estradiol. J Immunol. (2009) 183:759-69. doi: 10.4049/jimmunol.0803654

222. Tsuda S, Zhang X, Hamana H, Shima T, Ushijima A, Tsuda K, et al. Clonally expanded decidual effector regulatory $\mathrm{t}$ cells increase in late gestation of normal pregnancy, but not in preeclampsia, in humans. Front Immunol. (2018) 9:1934. doi: 10.3389/fimmu.2018.01934

223. Yao Y, Li H, Ding J, Xia Y, Wang L. Progesterone impairs antigen-nonspecific immune protection by CD8 T memory cells via interferongamma gene hypermethylation. PLoS Pathog. (2017) 13:e1006736. doi: 10.1371/journal.ppat.1006736

224. Cummings RD. T cells are Smad'ly in love with galectin-9. Immunity. (2014) 41:171-3. doi: 10.1016/j.immuni.2014.08.001

225. Zhu C, Anderson AC, Schubart A, Xiong H, Imitola J, Khoury SJ, et al. The Tim-3 ligand galectin-9 negatively regulates T helper type 1 immunity. Nat Immunol. (2005) 6:1245-52. doi: 10.1038/ni1271

226. Wu C, Thalhamer T, Franca RF, Xiao S, Wang C, Hotta C, et al. Galectin9-CD44 interaction enhances stability and function of adaptive regulatory $\mathrm{T}$ cells. Immunity. (2014) 41:270-82. doi: 10.1016/j.immuni.2014.06.011

227. Lajko A, Meggyes M, Polgar B, Szereday L. The immunological effect of Galectin-9/TIM-3 pathway after low dose Mifepristone treatment in mice at 14.5 day of pregnancy. PLoS ONE. (2018) 13:e0194870. doi: 10.1371/journal.pone.0194870

228. Alter G, Malenfant JM, Altfeld M. CD107a as a functional marker for the identification of natural killer cell activity. J Immunol Methods. (2004) 294:15-22. doi: 10.1016/j.jim.2004.08.008

229. Arruvito L, Giulianelli S, Flores AC, Paladino N, Barboza M, Lanari C, et al. NK cells expressing a progesterone receptor are susceptible to progesterone-induced apoptosis. J Immunol. (2008) 180:5746-53. doi: 10.4049/jimmunol.180.8.5746

230. Henderson TA, Saunders PT, Moffett-King A, Groome NP, Critchley HO. Steroid receptor expression in uterine natural killer cells. J Clin Endocrinol Metab. (2003) 88:440-9. doi: 10.1210/jc.2002-021174

231. Kitaya K, Yasuda J, Nakayama T, Fushiki S, Honjo H. Effect of female sex steroids on human endometrial CD16neg CD56bright natural killer cells. Fertil Steril. (2003) 79(Suppl. 1):730-4. doi: 10.1016/S0015-0282(02)04818-5

232. Szekeres-Bartho J, Par G, Dombay Gy, Smart YC, Volgyi Z. The antiabortive effect of progesterone-induced blocking factor in mice is manifested by modulating NK activity. Cell Immunol. (1997) 177:194-9. doi: 10.1006/cimm.1997.1090

233. Szekeres-Bartho J, Kinsky R, Chaouat G. The effect of a progesteroneinduced immunologic blocking factor on NK-mediated resorption. Am J Reprod Immunol. (1990) 24:105-7. doi: 10.1111/j.1600-0897.1990.tb01047.x

234. Bogdan A, Berta G, Szekeres-Bartho J. PIBF positive uterine NK cells in the mouse decidua. J Reprod Immunol. (2017) 119:38-43. doi: $10.1016 /$ j.jri.2016.12.001

235. Lee S, Kim J, Jang B, Hur S, Jung U, Kil K, et al. Fluctuation of peripheral blood T, B, and NK cells during a menstrual cycle of normal healthy women. J Immunol. (2010) 185:756-62. doi: 10.4049/jimmunol.0 904192

236. Lorenz TK, Heiman JR, Demas GE. Sexual activity modulates shifts in TH1/TH2 cytokine profile across the menstrual cycle: an observational study. Fertil Steril. (2015) 104:1513-21.e4. doi: 10.1016/j.fertnstert.2015.09.001

237. Arruvito L, Sanz M, Banham AH, Fainboim L. Expansion of $\mathrm{CD} 4+\mathrm{CD} 25+$ and FOXP3+ regulatory $\mathrm{T}$ cells during the follicular phase of the menstrual cycle: implications for human reproduction. J Immunol. (2007) 178:2572-8. doi: 10.4049/jimmunol.178.4.2572

238. Faas M, Bouman A, Moesa H, Heineman MJ, de Leij L, Schuiling G. The immune response during the luteal phase of the ovarian cycle: a Th2-type response? Fertil Steril. (2000) 74:1008-13. doi: 10.1016/S0015-0282(00)01553-3

239. Priyanka HP, Sharma U, Gopinath S, Sharma V, Hima L, ThyagaRajan S. Menstrual cycle and reproductive aging alters immune reactivity, NGF expression, antioxidant enzyme activities, and intracellular signaling pathways in the peripheral blood mononuclear cells of healthy women. Brain Behav Immun. (2013) 32:131-43. doi: 10.1016/j.bbi.2013.03.008

240. Caggiula AR, Stoney CM, Matthews KA, Owens JF, Davis MC, Rabin BS. Tlymphocyte reactivity during the menstrual cycle in women. Clin Immunol Immunopathol. (1990) 56:130-4. doi: 10.1016/0090-1229(90)90177-R

241. Lorenz TK, Heiman JR, Demas GE. Interactions among sexual activity, menstrual cycle phase, and immune function in healthy women. $J$ Sex Res. (2017) 1087-95. doi: 10.1080/00224499.2017.1394961

242. Rowe JH, Ertelt JM, Xin L, Way SS. Pregnancy imprints regulatory memory that sustains anergy to fetal antigen. Nature. (2012) 490:102-6. doi: 10.1038/nature11462

243. Nilsson B, Ferno M, von Schoultz B. Estrogen and progesterone receptors in the human thymus. Gynecol Obstet Invest. (1990) 29:289-91. doi: $10.1159 / 000293337$

244. Medina KL, Kincade PW. Pregnancy-related steroids are potential negative regulators of B lymphopoiesis. Proc Natl Acad Sci USA. (1994) 91:5382-6. doi: $10.1073 /$ pnas.91.12.5382

245. Zhang L, Chang KK, Li MQ, Li DJ, Yao XY. Mouse endometrial stromal cells and progesterone inhibit the activation and regulate the differentiation and antibody secretion of mouse B cells. Int J Clin Exp Pathol. (2014) 7:123-33.

246. Pauklin S, Petersen-Mahrt SK. Progesterone inhibits activation-induced deaminase by binding to the promoter. J Immunol. (2009) 183:1238-44. doi: 10.4049/jimmunol.0803915

247. Pham P, Afif SA, Shimoda M, Maeda K, Sakaguchi N, Pedersen LC, et al. Structural analysis of the activation-induced deoxycytidine deaminase required in immunoglobulin diversification. DNA Repair. (2016) 43:48-56. doi: 10.1016/j.dnarep.2016.05.029

248. Hall OJ, Nachbagauer R, Vermillion MS, Fink AL, Phuong V, Krammer F, et al. Progesterone-based contraceptives reduce adaptive immune responses and protection against sequential influenza A virus infections. J Virol. (2017) 91:e02160. doi: 10.1128/JVI.02160-16

249. Kelemen K, Bognar I, Paal M, Szekeres-Bartho J. A progesterone-induced protein increases the synthesis of asymmetric antibodies. Cell Immunol. (1996) 167:129-34. doi: 10.1006/cimm.1996.0016

250. Dressing GE, Goldberg JE, Charles NJ, Schwertfeger KL, Lange CA. Membrane progesterone receptor expression in mammalian tissues: a review of regulation and physiological implications. Steroids. (2011) 76:11-7. doi: 10.1016/j.steroids.2010. 09.006

251. Losel RM, Falkenstein E, Feuring M, Schultz A, Tillmann HC, RossolHaseroth K, et al. Nongenomic steroid action: controversies, questions, and answers. Physiol Rev. (2003) 83:965-1016. doi: 10.1152/physrev.00003.2003

252. Chien CH, Lai JN, Liao CF, Wang OY, Lu LM, Huang MI, et al. Mifepristone acts as progesterone antagonist of non-genomic responses but inhibits phytohemagglutinin-induced proliferation in human T cells. Hum Reprod. (2009) 24:1968-75. doi: 10.1093/humrep/dep099

253. Szekeres-Bartho J, Autran B, Debre P, Andreu G, Denver L, Chaouat G. Immunoregulatory effects of a suppressor factor from healthy pregnant women's lymphocytes after progesterone induction. Cell Immunol. (1989) 122:281-94. doi: 10.1016/0008-8749(89)90077-4

254. Cohen RA, Check JH, Dougherty MP. Evidence that exposure to progesterone alone is a sufficient stimulus to cause a precipitous rise in the immunomodulatory protein the progesterone induced blocking factor (PIBF). J Assist Reprod Genet. (2016) 33:221-9. doi: 10.1007/s10815-015-0619-7

255. Lachmann M, Gelbmann D, Kalman E, Polgar B, Buschle M, Von Gabain A, et al. PIBF (progesterone induced blocking factor) is overexpressed in highly proliferating cells and associated with the centrosome. Int J Cancer. (2004) 112:51-60. doi: 10.1002/ijc.20326 
256. Gonzalez-Arenas A, Valadez-Cosmes P, Jimenez-Arellano C, Lopez-Sanchez M, Camacho-Arroyo I. Progesterone-induced blocking factor is hormonally regulated in human astrocytoma cells, and increases their growth through the IL-4R/JAK1/STAT6 pathway. J Steroid Biochem Mol Biol. (2014) 144(Pt B):463-70. doi: 10.1016/j.jsbmb.2014.09.007

257. Gutierrez-Rodriguez A, Hansberg-Pastor V, Camacho-Arroyo I. Proliferative and invasive effects of progesterone-induced blocking factor in human glioblastoma cells. Biomed Res Int. (2017) 2017:1295087. doi: $10.1155 / 2017 / 1295087$

258. de la Haba C, Palacio JR, Palkovics T, Szekeres-Bartho J, Morros A, Martinez P. Oxidative stress effect on progesterone-induced blocking factor (PIBF) binding to PIBF-receptor in lymphocytes. Biochim Biophys Acta. (2014) 1838:148-57. doi: 10.1016/j.bbamem.2013.08.006

259. Anderle C, Hammer A, Polgar B, Hartmann M, Wintersteiger R, Blaschitz A, et al. Human trophoblast cells express the immunomodulator progesterone-induced blocking factor. J Reprod Immunol. (2008) 79:26-36. doi: 10.1016/j.jri.2008.06.002

260. Madendag Y, Sahin E, Madendag IC, Sahin ME, Acmaz G, Karaman H. High immune expression of progesterone-induced blocking factor in epithelial ovarian cancer. Technol Cancer Res Treat. (2018) 17:1533033818783911. doi: $10.1177 / 1533033818783911$

261. Kozma N, Halasz M, Polgar B, Poehlmann TG, Markert UR, Palkovics $\mathrm{T}$, et al. Progesterone-induced blocking factor activates STAT6 via binding to a novel IL-4 receptor. J Immunol. (2006) 176:819-26. doi: 10.4049/jimmunol.176.2.819

262. Salomon LJ, Rozenberg P, Szekeres-Bartho J, Malagrida L, Giudicelli Y, Ville Y. Changes in progesterone-induced-blocking-factor expression rates following mifepristone administration in termination of pregnancy at 5 to 8 weeks. J Matern Fetal Neonatal Med. (2005) 17:353-6. doi: 10.1080/14767050500140370

263. Szekeres-Bartho J, Barakonyi A, Polgar B, Par G, Faust Z, Palkovics $\mathrm{T}$, et al. The role of gamma/delta $\mathrm{T}$ cells in progesterone-mediated immunomodulation during pregnancy: a review. Am J Reprod Immunol. (1999) 42:44-8. doi: 10.1111/j.1600-0897.1999.tb00464.x

264. Polgar B, Barakonyi A, Xynos I, Szekeres-Bartho J. The role of gamma/delta $\mathrm{T}$ cell receptor positive cells in pregnancy. Am J Reprod Immunol. (1999) 41:239-44. doi: 10.1111/j.1600-0897.1999.tb00433.x

265. Weintraub BC, Jackson MR, Hedrick SM. Gamma delta T cells can recognize nonclassical $\mathrm{MHC}$ in the absence of conventional antigenic peptides. $J$ Immunol. (1994) 153:3051-8.

266. Adams EJ, Gu S, Luoma AM. Human gamma delta $\mathrm{T}$ cells: evolution and ligand recognition. Cell Immunol. (2015) 296:31-40. doi: 10.1016/j.cellimm.2015.04.008

267. Szekeres-Bartho J, Weill BJ, Mike G, Houssin D, Chaouat G. Progesterone receptors in lymphocytes of liver-transplanted and transfused patients. Immunol Lett. (1989) 22:259-61. doi: 10.1016/0165-2478(89) 90162-4

268. Xin L, Ertelt JM, Rowe JH, Jiang TT, Kinder JM, Chaturvedi V, et al. Cutting edge: committed Th1 CD4+ T cell differentiation blocks pregnancyinduced Foxp3 expression with antigen-specific fetal loss. J Immunol. (2014) 192:2970-4. doi: 10.4049/jimmunol.1302678

269. Ivanova-Todorova E, Mourdjeva M, Kyurkchiev D, Bochev I, Stoyanova E, Dimitrov R, et al. HLA-G expression is up-regulated by progesterone in mesenchymal stem cells. Am J Reprod Immunol. (2009) 62:25-33. doi: 10.1111/j.1600-0897.2009.00707.x

270. Hunt JS, Petroff MG, McIntire RH, Ober C. HLA-G and immune tolerance in pregnancy. FASEB J. (2005) 19:681-93. doi: 10.1096/fj. 04-2078rev

271. Shah NM, Herasimtschuk AA, Boasso A, Benlahrech A, Fuchs D, Imami $\mathrm{N}$, et al. Changes in $\mathrm{T}$ cell and dendritic cell phenotype from mid to late pregnancy are indicative of a shift from immune tolerance to immune activation. Front Immunol. (2017) 8:1138. doi: 10.3389/fimmu.2017. 01138

272. Ivanova-Todorova E, Kyurkchiev DS, Nalbanski A, Timeva T, Shterev A, Kyurkchiev SD. Production and characterization of a novel monoclonal antibody against progesterone-induced blocking factor (PIBF). J Reprod Immunol. (2008) 78:94-101. doi: 10.1016/j.jri.2007.12.001
273. Hudić I, Szekeres-Bartho J, Stray-Pedersen B, Fatušić Z, Polgar B, EćimZlojutro V. Lower urinary and serum progesterone-induced blocking factor in women with preterm birth. J Reprod Immunol. (2016) 117:66-9. doi: 10.1016/j.jri.2016.07.003

274. Pallinger E, Bognar Z, Bogdan A, Csabai T, Abraham H, Szekeres-Bartho J. PIBF+ extracellular vesicles from mouse embryos affect IL-10 production by CD8+ cells. Sci Rep. (2018) 8:4662. doi: 10.1038/s41598-018-23112-Z

275. Szekeres-Bartho J, Reznikoff-Etievant MF, Varga P, Pichon MF, Varga Z, Chaouat G. Lymphocytic progesterone receptors in normal and pathological human pregnancy. J Reprod Immunol. (1989) 16:239-47. doi: 10.1016/0165-0378(89)90053-3

276. King A, Gardner L, Loke YW. Evaluation of oestrogen and progesterone receptor expression in uterine mucosal lymphocytes. Hum Reprod. (1996) 11:1079-82. doi: 10.1093/oxfordjournals.humrep.a019300

277. Szekeres-Bartho J, Faust Z, Varga P. The expression of a progesteroneinduced immunomodulatory protein in pregnancy lymphocytes. Am J Reprod Immunol. (1995) 34:342-8. doi: 10.1111/j.1600-0897.1995.tb00962.x

278. Shah NM. The in vitro Interrogation of the Immune System in Pregnancy. Imperial College London: Imperial College London (2016).

279. Szekeres-Bartho J, Wegmann TG. A progesterone-dependent immunomodulatory protein alters the Th1/Th2 balance. J Reprod Immunol. (1996) 31:81-95. doi: 10.1016/0165-0378(96)00964-3

280. Zenclussen AC, Gentile T, Kortebani G, Mazzolli A, Margni R. Asymmetric antibodies and pregnancy. Am J Reprod Immunol. (2001) 45:289-94. doi: 10.1111/j.8755-8920.2001.450504.x

281. Lone AM, Tasken K. Proinflammatory and immunoregulatory roles of eicosanoids in $\mathrm{T}$ cells. Front Immunol. (2013) 4:130. doi: 10.3389/fimmu.2013.00130

282. Zhao X, Liu L, Liu D, Fan H, Wang Y, Hu Y, et al. Progesterone enhances immunoregulatory activity of human mesenchymal stem cells via PGE2 and IL-6. Am J Reprod Immunol. (2012) 68:290-300. doi: 10.1111/j.1600-0897.2012.01163.x

283. Li H, Bradbury JA, Dackor RT, Edin ML, Graves JP, DeGraff LM, et al. Cyclooxygenase-2 regulates Th17 cell differentiation during allergic lung inflammation. Am J Respir Crit Care Med. (2011) 184:37-49. doi: $10.1164 / \mathrm{rccm} .201010-1637$ OC

284. Maseda D, Johnson EM, Nyhoff LE, Baron B, Kojima F, Wilhelm AJ, et al. mPGES1-dependent prostaglandin E. J Immunol. (2018) 200:725-36. doi: 10.4049/jimmunol.1601808

285. Carlsson JA, Wold AE, Sandberg AS, Östman SM. The polyunsaturated fatty acids arachidonic acid and docosahexaenoic acid induce mouse dendritic cells maturation but reduce T-cell responses in vitro. PLoS ONE. (2015) 10:e0143741. doi: 10.1371/journal.pone. 0143741

286. Guo W, Li P, Zhao G, Fan H, Hu Y, Hou Y. Glucocorticoid receptor mediates the effect of progesterone on uterine natural killer cells. Am J Reprod Immunol. (2012) 67:463-73. doi: 10.1111/j.1600-0897.2012.01114.x

287. Check JH, Sansoucie L, Chern J, Amadi N, Katz Y. The effect of treatment with a progesterone receptor antagonist on death from spontaneous lymphocytic leukemia in AKR/J mice. Cancer Res. (2006) 66(8 Suppl.):61. Available online at: http://cancerres.aacrjournals.org/ content/66/8_Supplement/61.2.article-info

288. Batra S, Bengtsson LP, SjÖBerg NO. Interrelations between plasma and tissue concentrations of $17 \beta$-oestradiol and progesterone during human pregnancy. Clin Endocrinol. (1979) 11:603-10.

Conflict of Interest Statement: The authors declare that the research was conducted in the absence of any commercial or financial relationships that could be construed as a potential conflict of interest.

Copyright (c) 2019 Shah, Lai, Imami and Johnson. This is an open-access article distributed under the terms of the Creative Commons Attribution License (CC BY). The use, distribution or reproduction in other forums is permitted, provided the original author(s) and the copyright owner(s) are credited and that the original publication in this journal is cited, in accordance with accepted academic practice. No use, distribution or reproduction is permitted which does not comply with these terms. 